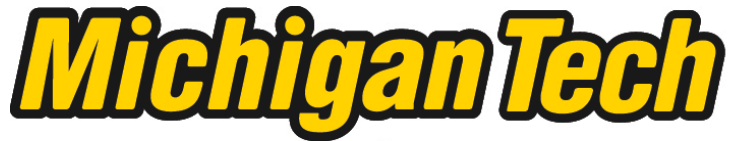 \\ Michigan Technological University Create the Future Digital Commons @ Michigan Tech
}

2014

\section{INCORPORATING REAL SCIENCE INTO THE SECONDARY CLASSROOM: AEROSOLS AND CLIMATE CHANGE}

Lorentyna M. Harkness

Michigan Technological University

Follow this and additional works at: https://digitalcommons.mtu.edu/etds

Part of the Science and Mathematics Education Commons

Copyright 2014 Lorentyna M. Harkness

\section{Recommended Citation}

Harkness, Lorentyna M., "INCORPORATING REAL SCIENCE INTO THE SECONDARY CLASSROOM: AEROSOLS AND CLIMATE CHANGE", Master's report, Michigan Technological University, 2014.

https://doi.org/10.37099/mtu.dc.etds/882

Follow this and additional works at: https://digitalcommons.mtu.edu/etds

8 Part of the Science and Mathematics Education Commons 


\title{
INCORPORATING REAL SCIENCE INTO THE SECONDARY CLASSROOM: AEROSOLS AND CLIMATE CHANGE
}

By

Lorentyna M. Harkness

\author{
A REPORT \\ Submitted in partial fulfillment of the requirements for the degree of \\ MASTER OF SCIENCE \\ In Applied Science Education \\ MICHIGAN TECHNOLOGICAL UNIVERSITY \\ 2014 \\ (C) 2014 Lorentyna M. Harkness
}



This report has been approved in partial fulfillment of the requirements for the Degree of MASTER OF SCIENCE in Applied Science Education

Department of Cognitive and Learning Sciences
Report Advisor: Dr. Bradley Baltensperger
Committee Member: Dr. Jacqueline Huntoon
Committee Member: Dr. Lynn Mazzoleni
Department Chair: Dr. Susan Amato-Henderson 



\section{ACKNOWLEDGMENTS}

I would first like to thank my husband and family who have supported me in this journey and understood all the times I had to travel for long periods of time in order to complete this endeavor. I also want to thank my advisor and committee for their help and patience. Thank you to Lynn Mazzoleni and her team for including me in the Pico Project. Finally, thank you to Bill Rose and the MiTEP team, without them, none of this would have been possible. 



\begin{abstract}
Climate science and climate change are included in the Next Generation Science Standards, curriculum standards that were released in 2013. How to incorporate these topics, especially climate change, has been a difficult task for teachers. A team of scientists are studying aerosols in the free troposphere; what their properties are, how they change while in the atmosphere and where they came from. Lessons were created based on this real, ongoing scientific research being conducted in the Azores. During these activities, students are exposed to what scientists actually do in the form of videos and participate in similar tasks such as conducting experiments, collecting data, and analyzing data. At the conclusion of the lessons, students will form conclusions based on the evidence they have at the time.
\end{abstract}





\section{INTRODUCTION}

In 2013, the Next Generation Science Standards (NGSS) were released. A group including 26 state partners developed these new standards based on the guidance contained within $A$ Framework for K-12 Science Education by the National Research Council. As of March 2014, ten states have adopted NGSS as their science curriculum standards and several other states were seriously considering them (Workosky, 2014). Among other changes from pre-existing curriculum standards, these new standards include engineering principles, as well as an introduction of climate science at the middle school level. At the high school level, students will be exposed to topics regarding human effects on climate (NCSE).

The need for new standards was great. States have been using the National Science Education Standards (National Research Council, 1996) and the Benchmarks for Science Literacy (American Association for the Advancement of Science, 1993), both of which are nearly twenty years old, to form their own state science standards. Careers are changing and the need for students' understanding of math, science, and engineering is greater now than in the past. This need is underscored by the fact that the United States lags, in terms of math and science education, behind the rest of the world.

The NGSS were developed using various elements from A Framework for K-12 Science Education, which was released in 2011. The Framework emphasizes science and engineering principles, disciplinary core ideas, crosscutting concepts and connections to nature of science. There are several standards regarding climate science including these two from the high school weather and climate standards:

HS-ESS2-4: Use a model to describe how variations in the flow of energy into and out of Earth's systems result in changes in climate.

HS-ESS3-5: Analyze geoscience data and the results from global climate models to make an evidence-based forecast of the current rate of global or regional climate change and associated future impacts to Earth systems. (nextgenscience.org) 
There is a strong need to include climate change in the NGSS due to the many misconceptions surrounding it. Climate change has been, and will continue to be, a hot political topic and it is imperative to enhance climate literacy so citizens can make informed decisions. There is difficulty surrounding the communication of climate change due to its complex nature. So many factors affect our atmosphere and climate that it is not easy to determine the cause of the problem. Michael Mann (2014) discusses some of these factors including anthropogenic activity, feedback mechanisms by clouds, sea ice and water vapor and ocean surface temperatures. Climate change can have effects on all aspects of human life; from the economy and environment to health and security. In 2009 a second version of a guide for climate literacy was developed by the United States Global Change Research Program. This guide contained essential principles of climate science that are "supported by fundamental concepts comparable to those underlying the National Science Education Standards and the American Association for the Advancement of Science Benchmarks for Science Literacy" (U.S. Global Change Research Program, 2009). The climate literacy guide contains seven essential principles that are important for students and adults to understand regarding Earth's climate. Each principle is supported by at least five subtopics explaining that principle. The guide serves several purposes, including being a resource to those who teach climate science.

One small part of climate change is atmospheric aerosols, which are not well understood. Aerosols are transported to the atmosphere through numerous events every day; both natural and anthropogenic (human-caused). They originate from biomass and fossil fuel burning, vehicle exhaust, volcanic eruptions, and sea salt, mineral dust and soil suspended by wind. Some of these aerosols can be propelled high enough in the atmosphere that they are able to travel long distances. These aerosols include dust, organic carbon, and black carbon and can absorb or scatter energy coming from the sun. Some can affect cloud formation and impact the regional atmosphere and climate change. Overall, aerosols mask the warming effect of greenhouse gases. 
The main question is not why to include climate change, but how to incorporate climate change standards into the classroom. This can be challenging and, at times, controversial. It is important to provide teachers with tools to incorporate new topics. This paper will examine literature regarding teaching climate change, and provide a unit to include in classroom teaching pertaining to climate change based on real world scientific research.

\section{LITERATURE REVIEW}

Seven journal articles published between 1996 and 2011 were reviewed to identify methods of teaching climate change. Climate change is controversial and one article was devoted to teaching controversial topics. Misconceptions held by students were discussed as well as how those misconceptions are addressed in textbooks. While most articles discussed why it is important to include climate change, some provided insight into how to best incorporate it in the classroom. Articles examining the need to take an integrated approach to climate change were also reviewed. Finally, specific lessons and activities regarding climate change were examined.

Controversy surrounds several topics in the science classroom, including climate change, evolution, nuclear energy, deforestation and AIDS. Cross and Price (1996) interviewed teachers in Scotland and the United States regarding how they approach controversial topics. Their research addressed the teachers' perceptions of teaching controversial topics, handling of personal positions, the tension between traditional science curriculum and the teaching controversial issues. Teachers feel the pressure of teaching all the content required by their state, and that leaves very little time for elaborating on certain topics. However, when teachers keep topics simple and to the point, students miss out on depth of the topic and the process of science.

When asked if they should discuss some issues regardless of their political implications, teachers felt it was their responsibility to fully educate their students to be leaders of the country. One teacher from Scotland said it is impossible to teach gene transfer without 
including the ethical, economic and political issues. This same teacher explained teaching science as helping students become socially aware. Teachers also feel it is their responsibility to explain how scientific information can be misused so students have an understanding that some information can be used that way, as can be the case in the media. Teachers believe that students should be able to investigate and determine their own results and learn the process of science instead of having information shoved at them. Teachers do also feel it is difficult to teach certain topics without interjecting their own personal beliefs. Students should be presented with "what the data is now and show them both sides of the issue, and show them how at this present moment there is absolutely no definitive answer," said one U.S. teacher (Cross and Price, 1996).

Results of these interviews led the researchers to suspect that while teachers were including controversial topics in their classrooms, they were not giving students the opportunity to develop questions, conduct investigations and make their own decisions regarding those topics. Teachers also felt it was difficult to obtain resources for teaching controversial topics. The researchers believe that providing teachers with methods to develop and obtain resources for teaching controversial topics is an urgent task (Cross and Price, 1996).

While climate change is controversial, it is being taught, but not without misconceptions. According to Webster's New World College Dictionary, the prefix "mis-" means "bad", or "wrong". A person can have an idea regarding a scientific topic that is unfavorable or does not follow the ideas of the scientific community and can exist for a variety of reasons. The media is one influential source of misconceptions; not everything on television, in newspapers and on the internet is complete and true. How climate change is taught in middle and high school provides another source of misconceptions. It has been found that students enter college with several misconceptions regarding climate change that should have been addressed earlier (Cordero, 2008). The purpose of one study regarding misconceptions about climate change was to analyze climate change concepts in commonly used science textbooks and how they could possibly contribute to students' misconceptions. 
Choi, et al. (2010) identified 41 misconceptions students commonly hold regarding climate change. These surround larger aspects such as the causes, effects and resolution of climate change. Several misconceptions surround the idea of the type and source of radiation involved in the greenhouse effect. One of these misconceptions is UV rays are the type of radiation reaching Earth through the ozone hole and are the cause of the greenhouse effect. Heat coming from the sun, and radiation reflecting off the surface of the Earth are ideas surrounding misconceptions regarding the source of radiation involved in the greenhouse effect. Some students believe the ozone layer causing global warming, due to their thoughts that more energy can reach the surface and cool air can leave through the hole. About half the students had the misconception that any pollution (acid rain, air pollutants, car exhaust) can cause an increase in global temperature. Effects of climate change do not exist on a regional scale, according to some students (Choi, et al., 2010; Shepardson, 2011). Students also have ideas about climate change that are limited to a temperature increase and do not take into account feedback systems that exist within Earth's systems. An example of a feedback system involves aerosols (discussed below in the case study). As the temperature increases, conditions could become drier and as a result, particles could get lifted into the atmosphere by wind. Some of these particles, or aerosols, can become cloud condensation nuclei $(\mathrm{CCN})$ that water condenses on to form clouds. Since clouds have a high albedo (reflect sunlight), the air temperature actually cools.

Once misconceptions were identified, researchers then looked at seven commonly used science textbooks in the United States. Specific scientific climate change concepts were listed based on those misconception and the textbooks were reviewed based on those 18 concepts. Only three of the concepts, distinction between greenhouse effect and climate change, major sources and the kinds of greenhouse gases, and the mechanism of the greenhouse effect, were covered in all seven textbooks. The distinction between pollution and the greenhouse effect or climate change was not covered in any of the textbooks reviewed and students have trouble with that concept. In fact, about half of the concepts were not covered in the textbooks. One misconception held by students is that greenhouse gases and dust exist in a single layer in the atmosphere. Six of the textbooks failed to mention that greenhouse gases 
are evenly distributed in the atmosphere, not in a single layer. The diagrams in the textbooks even illustrated the gases existing in a layer, which only fuels the students' misconception (Choi et al. 2010).

Students believe that climate change is not already affecting Earth and that it will not do so in their lifetimes. This misconception is also fueled by textbooks, and several of them fail to mention that climate change has already impacted Earth (Choi et al. 2010; Shepardson et al. 2011). Similarly, students have various viewpoints regarding humans' ability to control impacts of climate change. They also hold the belief that using renewable energy sources and planting more trees will solve the climate change problem (Shepardson et al. 2011). Only one textbook addressed climate change scenarios and another one addressed humans' dependence on fossil fuels (Choi et al. 2010).

While textbooks are not the only educational tool teachers use, Choi et al. suggest writing those science textbooks with students' misconceptions in mind. It is important to present concepts in a way that will correct those misconceptions. They also suggest collaboration among scientists, textbook publishers and teachers to develop appropriate educational materials. As discussed above, teachers can also convey their views on controversial topics, such as climate change. If these views are incorrect, teachers could add to students' misconceptions. Along with collaborating to make decisions regarding textbook material, teachers also need to receive training on climate change to help their students understand this difficult topic (Choi et al. 2010).

Moser and Dilling (2004) discussed seven strategies for communicating climate change. People tend to dismiss information regarding topics such as climate change if it comes from sources they do not trust or is uncertain, unspecific or perceived as manipulative. Each of the strategies will not fully communicate the important of climate change on their own; they all need to be used. The first strategy, "abide by basic communication rules", discusses the importance of learning who the audience is and who the communicator should be. Knowing the audience will guide in developing the appropriate presentation in ways the audience can 
understand. The second strategy is "address the emotional and temporal components of "urgency." The communicator should not use fear as motivation but explain the implications of climate change is nothing is done immediately, or at all. The communicator also needs to explain what steps can be done in ways that the audience will remember and will take action.

"Increase the persuasiveness of the message" is the next strategy discussed by Moser and Dilling. Discussing the most important concepts at the beginning of the discussion will almost guarantee the audience will remember the take-home message. Most importantly, the communicator must be careful not to make climate change only an environmental issue. Yes, a change in temperature does affect the environment but with that comes changes to several other aspects of our communities. Precipitation changes can lead to farming issues which can affect the economy. Droughts affect the water supply which can have political effects. More dust in the air can lead to more cases of asthma. All of these changes affect the plants and animals in the environment.

The fourth strategy is "use trusted messengers: broadening the circle". Individuals will brush off difficult topics such as climate change if they are not presented by a credible, reliable source. Different aspects of climate change should be presented by experts of those aspects. As the article states, "an economist will carry more weight than a climate scientist in speaking to the options of cost and feasibility of certain solutions" (Moser and Dilling 2004).

"Use opportunities well" is the fifth strategy in communicating climate change. Most, if not all, teachers know the importance of "teachable moments" and use them to their advantage. If a classroom is learning about plate tectonics and a large earthquake occurs somewhere in the world, or even their own country, it would be in the teacher's best interest to address that so students learn the real world aspects of earthquakes and plate tectonics. Teachable moments allow teachers to make the information meaningful to their students and link it to their lives. In turn, students tend to remember those moments longer. The sixth strategy is "tap into individual and cultural strengths and values". Communicators should present information in a way that reaches their audience's values. In this way the audience is more 
apt to receive the information and take action. If they feel that it relates to them, they are more willing to listen and act.

The final strategy, "unite and conquer" discusses bringing together aspects of climate change and bringing together people to solve the problem. Examining one instance of climate change will not convince the audience that there is a problem, but examining multiple changes in patterns will. Also, one person cannot solve the climate change issue, but if every person changes one thing it will make an impact (Moser and Dilling 2004). If teachers follow these seven strategies, they can effectively communicate climate change to their students.

Another method of incorporating climate change into the classroom is integration. When taught using this approach, students understand more aspects and implications of climate change (NOAA 2009). As discussed above, misconceptions surround this topic and can be a result of not being able to connect interrelated concepts. For example, students may not understand how different atmospheric gases selectively absorb radiation and that can lead to misconceptions about the types of radiation involved in the greenhouse effect (Choi et al. 2010). Understanding only the causes of climate change and the effect on global temperatures and precipitation will not be enough to change society's feelings about the topic. If a predominately agricultural area experiences higher than normal temperatures and less precipitation, it could not only impact the livelihood of the farmers, but also the greater economy and food sources for a larger population. Climate change will have implications for economies, infrastructure, and governmental policies that students need to understand (NOAA 2009).

As discussed in Fortner (2001), a goal of scientific literacy is an interdisciplinary curriculum. There are concepts in all branches of science (biology/life, chemistry, physics, Earth/space science, and environmental science) that deal with climate change. Using an Earth systems approach will allow for instruction of many parts of climate change and how they relate to each other, regardless of the specific science discipline. For example, in a physics class, the biology would most likely not be discussed and in chemistry, the space science could be 
ignored. This would not be so in a systems approach (Fortner 2001). If students understand how science is interrelated, they can begin to understand climate change from a range of approaches. Lessons on climate change can also include material from classes other than science. Math can be integrated using graphs and modeling, and language arts can be used in the form of novels, films and debates. Using integration can help students understand how topics they learn in school are applied in the real world, such as graph analysis, algebra and modeling (Rule 2009).

There are difficulties with using an integrated approach to teaching climate change however. Climate change is a relatively new topic taught in schools and many teachers may not have studied it themselves. Teachers are most likely to be skilled in only one or two branches of science and not in interdisciplinary sciences. Teachers already face an overcrowded curriculum and are faced with pacing that leaves little room for extras. This could cause them to not want to go into further detail on interrelated concepts just because there isn't time. Again, further training may need to be required for teachers to effectively teach climate change (Fortner 2001).

Finally, two articles reviewed lessons used in the classroom demonstrating various aspects of climate change will be discussed here. One such lesson, discussed by Rule and Meyer (2009), was used in an urban high school classroom with low test scores and high absenteeism. This lesson was structured in the 5-E format, which allows students to build on their knowledge from experiences. It also integrated several areas of science, math and social issues. Students were presented with various objects (plants or animals), graphs pertaining to the object and true or false statements that relate to the graphs. The objects and graphs were presented a way that grabbed the students' attention. First, the students were asked to explain how each plant or animal might show evidence for climate change. Many students did not know, which led to them wanting to find out more. Next, they examined the graphs and matched them to each object. The graphs contained real-world data and used a variety of sources. Several statements were presented and students had to analyze the graphs to determine if each statement was true or false. Finally, students watched and discussed videos pertaining 
to ecology and climate change. When asked about the lesson, students said they enjoyed it, liked studying animals in their environments and learning about the causes and effects of climate change. Students were also surprised to learn how animals were affected by climate change and the immediacy of the problem. As important as it is to teach the standards and skills students need, it is just as important to teach current events that require action on society's part (Rule and Meyer 2004).

The second article reviewed a lesson used in college classrooms, as some college students still hold misconceptions regarding climate change. Cordero, Todd and Abellera (2008) discussed an online activity, the Ecological Footprint, which professors used to engage students in understanding climate change and reflecting on their own choices and how they affect our planet. This activity asks a series of questions regarding the types of food one consumes, their travel, their homes, appliances and waste. At the end of the survey, the activity estimates the resources needed to sustain a population that acted in the same manner as the person who completed the survey. It illustrates how many Earth's would be needed and how many biologically productive acres the person uses. The activity also gives suggestions on how to lessen your ecological footprint. These vary from taking a local vacation instead of flying, or eating less animal products, or using public transportation at least once a week. By taking some or all of these suggestions, students can see how much their footprint can be reduced. This activity helped students dispel misconceptions and see how their actions affect the planet and provided motivation for the students to take action. The conclusion of this study was "that effective climate change education should emphasize the personal connection between the student, energy, and climate change using active learning methods" (Cordero et al. 2008).

Climate change is a current scientific and political topic and needs to be taught in secondary classrooms. According to Fortner 2001, "fewer than 3\% of US students have access to high school Earth Science courses". Several strategies should be used to effectively communicate the urgency of climate change. Due to its controversial nature, the science, as well as the economic, environmental and societal impacts, needs to be addressed. Misconceptions 
surround climate change and some textbooks have been shown to feed these

misconceptions. Additional material should be used in the classroom to enhance the learning of climate change concepts.

Several studies have shown that climate change should be taught with an integrated approach. It is difficult to talk about the meteorological concepts of climate change without talking about the chemical and physical properties of the dust and gases in the atmosphere or the biological effects of climate change on our planet. Students also need to be given a chance to analyze data and make connections of various aspects of climate change. They also need to see a personal connection to how they live and how it affects Earth. When this occurs, then students begin to take interest and start to take action.

\section{METHODS}

During the summer field season, I travelled to the Azores to observe and participate in research being conducted by a team of scientists from Michigan Technological University. Members of this team collected aerosol particles from the free troposphere and brought them back to the lab at the university for analysis. While in the field, and back at MTU, videos were filmed of various components of this research - explanation of collection, explanation of analysis, interviews with team members and the history of the station given by a professor in the Azores. These videos were uploaded to You'Tube and included in a series of lessons based on the aerosol research. The lessons were developed using actual data and reflect strategies discussed above. These lessons and links to the videos can be found in the appendences below.

\section{RESULTS}

In 2001, Michigan Technological University placed a station, with the help of the U.S. Air Force, in the caldera of Pico Mountain at an elevation of 2225 meters. Pico Mountain, with a summit elevation of 2351 meters, is located on the island of Pico in the Azores archipelago. 
Since it was established, the station has been donated to the University of the Azores and is currently used by team of scientists from the United States and Portugal. During the summer of 2013, this team continued their research on aerosols in the atmosphere, specifically in the free troposphere, and the effects of the aerosols on climate.

One goal of the Michigan Technological University scientific team is to present their research to a broader audience, specifically students. Complex, detailed research needed to be broken down in ways middle and high school students could understand. I developed a set of lessons with this goal in mind using data from the research and the pedagogical ideas discussed above. In order to write the lessons, several things had to occur, including visiting the station, participating in the research, and having conversations with scientists involved in the project. I visited the station twice to observe filter changes. One set of filters were collected from the high volume samplers and were later analyzed for chemical properties of the aerosols on those filters. Another set of filters are used to analyze the physical properties of aerosols; that analysis is done using a scanning electron microscope. Once back at the university, I assisted in the analysis of both types of filters. This participation gave more insight into how the scientists do their research. From there, conversations were had with members of the project team. These included topics such as why the station was placed on Pico Mountain, why collaboration is important, how each member became involved in the project, each member's specific role in the project, and how science is done in general.

After all these activities occurred, the various components of the project were broken down into lessons. This series of lessons contain activities using a variety of methods, from internet research, to analysis of graphs, hands-on experiments and videos of actual scientists collecting and analyzing data and explaining their role in the project. The lessons do not center on one discipline of science, but include chemistry, physics, modeling, technology, and collaboration. These lessons also address climate change on a regional scale. Students hold the misconception that climate change affects all areas of the globe in the same way. Another misconception students hold is that all pollution leads to global warming. One lesson shows them that some aerosols actually provide cooling. The videos used show actual 
scientists, experts in their field, collecting data and explaining how their work fits into the project as a whole. One video discusses what science is and how important it is to have several people working together to solve a problem because a single person cannot possibly know everything there is to know. At the conclusion of the lessons, students connect all the information they learned and data they gathered to explain how aerosols affect climate.

\section{CONCLUSION}

The lessons created for the Pico Project (below) were developed to reflect the ideas presented above. Students hold misconceptions regarding climate change and some of these lessons help correct those misconceptions. Several disciplines of science are integrated in these lessons so students learn how they are interconnected. The lessons were written with the 5-E Model and inquiry in mind. Teachers can use the level of inquiry they and their students are familiar with. They use a hands-on approach and through research, students learn that some of the aerosols from our area (North America) can travel as far as Europe.

The goals and standards listed for the lessons are met by the various activities the students will engage in. As students use the internet to explore Pico Mountain and its location, they will determine why it was ideal to place the station there. Students will use pictures of aerosols and classify the particles based on their structure and also if they have aged (did the particles travel long or short distances). Using weather data and graphs of amounts of carbon in the aerosols, students will identify pollution events and possible reasons for the events and where the pollution could have traveled from. Students will conduct their own experiments to explore how aerosols can warm and/or cool the atmosphere. By doing so they will describe how energy or waves are reflected or absorbed, as well as how those trends can create feedbacks that cause changes to other Earth systems. Finally, students will relate what they did in the classroom to what scientists do as they carry out their research.

The lessons created here are unique in that they are based on actual, ongoing scientific research on climate change. They include data collected in the field and analyzed in the lab; 
so instead of looking at hypothetical graphs in a textbook, students are exposed to what actual data and graphs look like. Students are also exposed to real scientists doing real science, whether it is in the field or in the lab. These scientists stress the importance of collaboration and working together to reach a common goal. Students will work with collected data in similar ways scientists analyze it. At the conclusion of the lessons, students will compile their data and evidence and use it to answer a scientific question regarding aerosols and climate change. 


\section{REFERENCES}

American Association for the Advancement of Science. Benchmarks for Science Literacy. New York: Oxford University Press, 1993.

Andreae, Meinrat O., and V Ramanathan. "Climate's Dark Forcings." Science 340 (2013): 28081. Web. 19 Apr. 2013.

Choi, Soyoung, Dev Niyogi, Daniel P. Shepardson, and Umarporn Charusombat. "Do Earth and Environmental Science Textbooks Promote Middle and High Schools Students' Conceptual Development about Climate Change? 'Textbooks' consideration of students misconceptions." Bulletin of American Meteorological Society 91.7 (2010): 889-98. Print.

Cordero, Eugene C., Anne Marie Todd, and Diana Abellera. "Climate Change Education and the Ecological Footprint." Bulletin of American Meteorological Society 89.6 (2008): 865-72. Print.

Cross, Roger T., and Ronald F. Price. "Science Teachers' Social Conscience and the Role of Controversial Issues in the Teaching of Science." Journal of Research in Science Teaching 33.3 (1996): 319-33. Print.

Dzepina, Katja, Christopher D. Cappa, Rainer M. Volkamer, Sasha Madronich, and et. al. "Modeling the Multiday Evolution and Aging of Secondary Organic Aerosol During MILAGRO 2006." Environ. Sci. Technol. 45 (2011): 3496-503. Print

"Evolution and climate change in the NGSS." National Center for Science Education. NCSE, 9 Apr. 2013. Web. 13 Feb. 2014. <http://ncse.com/news/2013/04/evolution-climatechange-ngss-0014800>.

Fortner, Rosanne W. "Climate Change in School: Where Does It Fit and How Ready are We?" Canadian Journal of Environmental Education 6 (2001): 18-31. Print. 
Hallquist, M., J.C. Wegner, U. Baltensperger, Y. Rudich, and et. al. "The formation, properties and impact of secondary organic aerosol: current and emerging issues." Atmos.

Chem. Phys. 9 (2009): 5155-236. Print.

Mann, Michael. "Earth Will Cross the Climate Danger Threshold by 2036." Scientific American. 310.4 (2014). Web. 28 July 2014.

"Mis-." Webster's New World College Dictionary. Third ed. 1997. 865. Print.

Moser, Susanne C., and Lisa Dilling. "Making Climate Hot: Communicating the Urgency and Challenge of Global Climate Change." Environment 46.10 (2004): 32-46. ProQuest. Web. 13 Feb. 2014.

Myhre, G, C.E. L. Myhre, B H. Samset, and T Storelvmo. "Aerosols and their Relation to Global Climate and Climate Sensitivity." Nature Education Knowledge 4.5 (2013): 7. Print.

National Research Council. A Framework for K-12 Science Education: Practices, Crosscutting Concepts, and Core Ideas. Committee on a Conceptual Framework for New K-12 Science Education Standards. Board on Science Education, Division of Behavioral and Social Sciences and Education. Washington, DC: The National Academies Press, 2012.

National Research Council. National Science Education Standards. 4th ed. Washington, D.C.: National Academy Press, 1996.

Next Generation Science Standards. Next Generation Science Standards. N.p., 2013. Web. 13 Feb. 2014. <http://nextgenscience.org>.

Poschl, Ulrich. "Atmospheric Aerosols: Composition, Transformation, Climate and Health Effects." Agnew. Chem. Int. Ed. 44 (2005): 7520-40. Print. 
Rule, Audrey C., and Mary A. Meyer. "Teaching Urban High Schools Students Global Climate Change Information and Graph Interpretation Skills Using Evidence from the Scientific Literature." Journal of Geoscience Education 57.5 (2009): 335-47.ProQuest. Web. 13 Feb. 2014.

Shepardson, Daniel P., Dev Niyogi, Soyoung Choi, and Umarporn Charusombat. "Students' conceptions about the greenhouse effect, global warming, and climate change." Climatic Change 104 (2011): 481-507. Print.

Stage, E. K., H. Asturias, T. Cheuk, P. A. Daro, and S. B. Hampton. "Opportunities and Challenges in Next Generation Standards." Science 340 (2013): 276-77. Web. 19 Apr. 2013. $<$ http://www.sciencemag.org $>$.

Workosky, Cindy. "Oregon Becomes 10th State (+DC) to Adopt the NGSS." NGSS@NSTA. NSTA, 7 Mar. 2014. Web.14 Mar. 2014. <http://ngss.nsta.org/2014/03/07/oregon-becomes-10th-state-dc-to-adopt-the-ngss/>. United States Global Change Research Program. Climate Literacy: The Essential Principles of Climate Science. Second ed. Washington, D.C.: U.S. Global Change Research Program, 2009. N. pag. Print. 


\section{APPENDIX A: PICO PROJECT LESSONS OVERVIEW \\ Pico Project: Effects of Aerosols on Climate}

\section{Overview and Background:}

$$
8^{\text {th }}-9^{\text {th }} \text { Grade }
$$

Atmospheric aerosols are not well understood, but important for climate change due to Earth's energy imbalance and health due to air quality. Aerosols are transported to the atmosphere through numerous events every day; both natural and anthropogenic. There are two types of aerosols, primary and secondary. Primary aerosols are emitted directly into the atmosphere and can originate from biomass and fossil fuel burning, car and truck exhaust, volcanic eruptions and sea salt, mineral dust and soil suspended by wind. Secondary aerosols are formed in the atmosphere from oxidation of primary emissions. Once an aerosol particle is in the atmosphere, it is chemically and physically altered by interactions with other gases and substances. This process is called atmospheric aging.

Many aerosols stay below the boundary layer, or first cloud layer in the atmosphere. The sources of those particles are usually local pollution or particles carried aloft in weather events. However, when an event is large enough, such as a forest fire, the heat propels the aerosols into the free troposphere, which exists above the boundary layer. Once there, the aerosols travel great distances because of a low concentration of ozone and other oxidants, which breakdown organic aerosols. The air in the free troposphere is not well mixed, and that is why we can see layers (brown layer indicates aerosols) at times. Unlike other greenhouse gases such as carbon dioxide $\left(\mathrm{CO}_{2}\right)$, methane $\left(\mathrm{CH}_{4}\right)$, and water vapor, aerosols are not long lived in the atmosphere; some lasting only weeks. Aerosol particles can absorb and scatter energy coming from the sun, affect cloud formation, and impact the regional atmosphere and climate change. Some aerosols, such as mineral dust and organic carbon, scatter the sun's radiation and produce a white haze. When this occurs, the aerosols are producing a cooling effect, since white particles reflect the sun's radiation. Other aerosols, such as black carbon, absorb the radiation, which produces a warming effect. Unlike greenhouse gases, which react with outgoing radiation, aerosols and clouds interact with 
incoming radiation. Overall, aerosols as a whole tend to have a cooling effect and thus "mask" the warming effect of greenhouse gases.

In 2001, Michigan Technological University placed a station, with the help of the U.S. Air Force, in the caldera of Pico Mountain, at an elevation of 2225 meters. Pico Mountain, with a peak elevation of 2351 meters, is located on the island of Pico of the Azores archipelago. Since the station was established, it has been donated to the University of the Azores and is currently used by team of scientists from the United States and Portugal. The scientists are researching those aerosols that are located in the free troposphere. When mountains on a continent are accessible, mainly in the summer, the boundary layer is too high and not below the mountain top. However, the marine boundary layer is lower than the continental boundary layer in the summer and below the top of Pico. Due to this, it is an ideal location to observe and study aerosols in the free troposphere. Another reason that makes Pico Mountain an ideal location is the cleanliness of the air. There is very little local pollution due to the island being located in the middle of the Atlantic; therefore, the aerosols collected are long range transported. Organic carbon (OC) and elemental, or black, carbon are among the aerosols being studied in the Pico project. Black carbon (BC) is the main warming constituent from anthropogenic sources and is short-lived, lasting only approximately one week. Even though BC is short-lived, large amounts are being emitted in large population centers - developing countries, India, and the like.

These set of lessons were created as an outreach tool for the Pico project. The focus is directed at late middle school to early high school students, although some of the activities can be adapted to meet the needs of higher grade levels. A "big idea" question would be given at the beginning of the unit and as the lessons progress, students collect data that would help them answer the question. An example could be, "What is the role of aerosols on climate?" Many of the activities students will participate in are based directly on research that is being conducted by the research team. Videos were recorded and photos were taken in the field (Pico Mountain) and in the lab at Michigan Technological University. At the end of the unit, students will be exposed to videos of members of the research team discussing 
the project and research in general. The major assessment for this unit will be a writing activity in which the students will argue a claim, provide evidence, analyze and interpret that evidence, and provide reasoning as to how their evidence relates to their claim. This activity echoes both science standards and Common Core literacy standards.

\section{Goals:}

- Based on answers to questions and introductory information, the learner will explain why Pico is an ideal location to study atmospheric aerosols.

- The learner will define aerosols and classify them based on their structure.

- Based on real, authentic data, the learner will identify the aging of aerosols reaching Pico Mountain.

- Based on real, authentic data, the learner will identify pollution events and propose explanations to them.

- Based on real, authentic data, the learner will determine the warming and/or cooling effects on the atmosphere by aerosols.

- The learner will provide evidence and reasoning to their claim of aerosols affecting the climate

- The learner will relate their participation in classroom activities to real, on-going scientific research

\section{Next Generation Science Standards:}

HS-ESS2-2: Analyze geoscience data to make the claim that one change to Earth's surface can create feedbacks that cause changes to other Earth systems. 
HS-ESS2.4: Use a model to describe how variations in the flow of energy into and out of Earth's systems result in changes in climate.

HS-ETS1-1: Analyze a major global challenge to specify qualitative and quantitative criteria and constraints for solutions that account for societal needs and wants.

MS-PS4-2: Develop and use a model to describe that waves are reflected, absorbed, or transmitted through various materials.

\section{Vocabulary:}

Absorption - light energy taken in by substance, causes warming

Aerosol - any small particle in the atmosphere

Albedo - the ability of a substance to reflect back light energy (snow - high albedo; blacktop - low albedo)

Anthropogenic - human caused

Black Carbon - pollutant from coal and diesel burning

Boundary Layer - first, or lowest, cloud layer

Cloud Condensation Nuclei - solid, suspended particles that provide a surface for water vapor to condense on

Elemental Carbon - includes some black carbon, basically soot or graphite

Free Troposphere - atmosphere above the first cloud layer

Organic Carbon - brown carbon, sources are biomass burning and atmospheric chemical reactions

Radiative Forcing - measure of how much energy goes back out to space subtracted from the amount of energy coming in from the sun; if the number is positive there is warming, if the number is negative there is cooling Scatter - light energy hits and bounces off a substance, causes cooling SEM - Scanning Electron Microscope Soot - black carbon, organic aerosol TEM - Transmission Election Microscope 
Materials: All the videos are on the YouTube channel "Pico Project Teaching and Outreach Videos". Link: http://www.youtube.com/channel/UCQdC-

aXRF1TFB5c1tVHSpeg. PowerPoint files are located on our website, http://pico-

mt.mtu.edu/education/.

Engage:

- Student handout

- Computers with internet access

- PowerPoint: Pico Project - 1 Engage

- Video: Pico Video - Introduction

Explore/Explain:

1. Classify and Measure

- Student copies of aerosol particle images

- PowerPoint: Pico Project - 2 Classify

- Video: Pico Video - Inside the ICO

- Rulers (if having students measure without computers)

- PowerPoint: Pico Project - 3 Measure

- Video: Pico Video - SEM

2. Chemistry

- Real data from Pico

- PowerPoint

- Video: Pico Video - High Volume Samplers

- Video: Pico Video - OC/EC

3. Scattering/Absorbing

- Lab handout

- Crushed ice (or snow, if available)

- Soot/ashes

- Plastic containers for ice (rope off snowy areas outside if done in the winter)

- Thermometers 
- PowerPoint

Elaborate:

- PowerPoint

- Student handout with questions

- Video: Pico Video - Elaborate pt1 and pt2

Evaluate:

- Claim-Evidence-Reasoning Rubric

\section{The Lesson Outline:}

Engage (1 class period)

1. Brief introduction of mini-unit and the Azores (PowerPoint)

2. Students explore the internet to find answers to questions provided. Students are encouraged to use websites provided and avoid those sites specified.

3. Discuss student's answers, without providing corrections

4. Watch introduction video which provides answers to most of the questions and also explains the project on Pico

Explore/Explain (4-6 class periods - each day there is exploration and explanation)

1. Classify aerosols
a. Discuss previous day's findings - make sure they have correct answers
b. Provide notes and examples of classification of aerosols (PowerPoint)
c. Students watch a video explaining how aerosols are collected
d. Students are given images of aerosols they must classify (in groups - soot or dust/mineral)

2. Measure aerosols

a. Watch video demonstrating how filter samples are prepared and photographed in the SEM 
b. Depending on the level of your students, you could provide measurements or have them work with the program to measure aerosols themselves.

c. Show example of a measured aerosol particle - explain what the measurements mean $($ Feret $=$ max length; MinFeret $=$ max width; Perim $=$ perimeter; Round = closer to 1 is "more round")

d. Work through an example with students

e. Students will work in groups to classify and measure aerosol particles

f. Discuss findings

3. Chemistry of aerosols

a. Show students video of collecting samples on Pico

b. Video of OC/EC

c. Look at data and determine events - look on previous weather data to propose a reason for the changes in the graph

4. Scattering and absorbing

a. Notes - albedo, scattering and absorption (PowerPoint)

b. Video: Bill Nye cloud in a bottle experiment (http://www.youtube.com/watch? $\mathrm{v}=\mathrm{nN} 9 \mathrm{e}$ bqDAl0)

c. Experiment: determine melting rate (warming) of pure snow or ice compared to snow or ice with soot

d. Students complete a lab report

e. Alternate experiment is provided (both guided inquiry and open inquiry)

Elaborate (1 class period)

1. Discussion on what science is and how scientists do science

2. Relate that to what the students did throughout the activities

3. Students watch video of scientists talking science and research

4. Take notes/answer questions during video 
Evaluate (2 class periods)

1. Overall effect of aerosols on climate

2. Students answer a scientific question in Claim - Evidence - Reasoning format

3. Grading will be based on the rubric and their ability to relate reasoning to their evidence and claim

\section{Assessment:}

- Formative assessment throughout

- Lab report

- Claim-Evidence-Reasoning writing at the end

\section{For More Information:}

www.pico-mt.mtu.edu

www.climate.gov 


\section{APPENDIX B: TEACHING NOTES}

\section{Teaching Notes - Pico Project: Introduction}

\section{Overview:}

The purpose of this lesson is for students to familiarize themselves with Pico Mountain where it is located, its elevation, and characteristics of the mountain - and start to understand why Pico is ideal for studying the free troposphere. Although several websites will give the correct information, try to steer students clear of certain, unscientific, sites. In this case, Wikipedia does provide the correct elevation and characteristics of the mountain.

\section{The Lesson:}

To start the lesson, use the PowerPoint provided.

- Slide 1 - Picture of Pico Mountain in the Azores

- Slide 2 - Introduction - why this research is being conducted

- Slide 3-Goals of the unit

- Slide 4 - Purpose - why Pico is being used to help teach climate science

- Slide 5 - The day's task

- Slide 6-Approximately 4 minutes - Video introduction to the Pico Project.

- Slide 7 - Google Earth image with part of the hike marked using GPS

Give students ample time to research the answers to the questions on their handout. A time of 20 minutes is suggested, but use more or less depending on your students. At the end of research time, DO NOT go over the answers. The video introduction will also provide some of the answers. If time allows, the video can be shown twice to give time for the students to write down answers they may have missed. If you still have time at the end, go over the answers. They can be found on slides 8-10. It is important for students to understand why research stations, such as ones located on Pico, Mauna Loa in Hawaii, in Germany, are located where they are. If the station was placed further down the mountain, aerosols from the free troposphere would not be obtained. This lesson would also give an opportunity to review plate tectonics, why volcanoes are located in the Azores, and the types of volcanoes.

\section{Answers:}

1. Find the elevation of Pico Mountain (Careful - this is not in the United States!) $2351 \mathrm{~m}(7713 \mathrm{ft})$

2. Where is Pico Mountain located? (be specific)

On the island of Pico in the Azores archipelago; islands are located along the Mid-Atlantic Ridge and are situated on 3 plates in the North Atlantic Ocean (North American, Eurasian, and African)

3. Describe the mountain. 
Inactive stratovolcano, last eruption was in the 1700 s

Caldera - summit crater at an elevation of $2225 \mathrm{~m}$ (7299 ft)

Piquinho (small volcanic cone) - true summit of the mountain

(any other descriptions students use regarding slope, size, location on the island, color, etc)

4. What is the boundary layer in terms of the atmosphere?

The first cloud layer

5. What is the free troposphere?

The air above the first cloud layer

6. What is the altitude of the marine boundary layer?

$1200-1600 \mathrm{~m}$

Why is Pico Mountain a good place to study the atmosphere?

(Give students time to explain their answers) The station is above the first cloud layer. The air in the free troposphere carries aerosols from North America and is generally clean. This means it is free from local pollution. Local pollution or pollution created a short distance away does not enter the free troposphere. The aerosols collected on Pico could be from Canada, northern United States, Africa, and possibly Europe. If the particles get swept up into the free troposphere, the jet stream and other wind belts can carry them to Pico. 


\section{Teaching Notes - Classifying and Measuring Aerosol Particles}

\section{Overview:}

The purpose of this lesson is to learn how aerosol particles are collected, imaged, classified and measured. Students will watch videos of the collection process in the Pico Mountain Observatory and the imaging process in the lab at Michigan Technological University. Even though students will be measuring the particles with rulers, it is similar to how the scientists measure particles using a computer program. This lesson will take at least 2 - 55 minute class periods.

\section{The Lesson:}

To start the lesson, use the PowerPoint provided.

Day 1 Classify

- Slide 1 - Intro slide showing SEM (Scanning Electron Microscopy) images

- Slides 2-4 - Answers to previous day's questions

- Slide 5 - Picture showing the ICO (International Chemistry Observatory) on Pico Mountain

- Slide 6 - Notes on aerosols

- Slide 7 - Notes on transport of aerosols

- Slide 8-Graphic illustrating local pollution and long range transport

- Slide 9 - Video questions for students to answer

- Slide 10 - Approximately 7 minute long video of aerosol collection in the ICO

- Slide 11 - Differences between soot and dust with today's task (end of classification portion of lesson)

Day 2 Measure

- Slide 1 - Measuring aerosols intro showing the outcome using ImageJ (the computer program scientists use to measure aerosol particles)

- Slide 2 - Notes - what happens to soot as it travels

- Slide 3 - Photos of aerosol particles at different stages of aging

- Slide 4 - Video questions for students to answer

- Slide 5 - Approximately 8 minute long video of SEM imaging

- Slide 6-Directions on how to measure particles

Discuss the answers to the introduction questions if you didn't have time the previous day to do so. Next, discuss what an aerosol is (small particle in the air). Soot is an organic aerosol; it contains carbon. Dust is mineral and could be from deserts in Africa. There are other places dust could come from, China for example, but that dust would not be collected on Pico. The color of the aerosol particles determines scattering or absorption of the sun's radiation (to be discussed in an upcoming lesson). Aerosols can be transported in two ways; local pollution stays below the boundary layer and, therefore, is not collected on Pico. Aerosol that is longrange transported can have a source in the United States, Canada, Africa, and on a rare 
occasion, Europe and travels in the free troposphere to Pico. This is what scientists on Pico are concerned with. On the graphic illustrating pollution, point out the boundary layer and note that the summit of Pico Mountain is just above it. Have students write down the two video questions and answer them during the video. The video on slide 17 was taken in the ICO on Pico Mountain. Inside are several instruments and one contains filters for scanning electron microscopy and transmission electron microscopy. Aerosols are collected on those filters and students will observe how they are changed. Finally, hand out the packet of particle images. Students should first classify the particle as either soot or dust.

On Day 2 of this lesson, students will measure the aerosol particles they classified the previous day. The first slide for this day is slide 19 and it depicts the before image and after image using ImageJ, a computer software program used to measure particles. It also shows how the measurement results are displayed in microns. The measurements students will be looking at are "Perim" (perimeter), "Feret" (max. length), and "MinFeret" (max. width). Scientists also look at the area and roundness. In terms of roundness, the closer to 1.00 the measurement is, the rounder it is. For example, the soot particle in image 2 has a roundness of 0.482 and the smaller, soot particle on image 5 has a roundness of 0.896 . The rounder and more compact a particle is, the more the particle has aged (been in the atmosphere longer). The video for this lesson explains how filter samples are prepared for the SEM and images taken. This was filmed in the lab at Michigan Technological University. For more information on the microscope, visit http://electronmicroscopy.org/More Resources.htm and click on "Hitachi S-4700 FE-SEM" on the left side column. There you will find resources pertaining to the microscope used to make these images. Follow the directions below as an example of how to measure the particles.

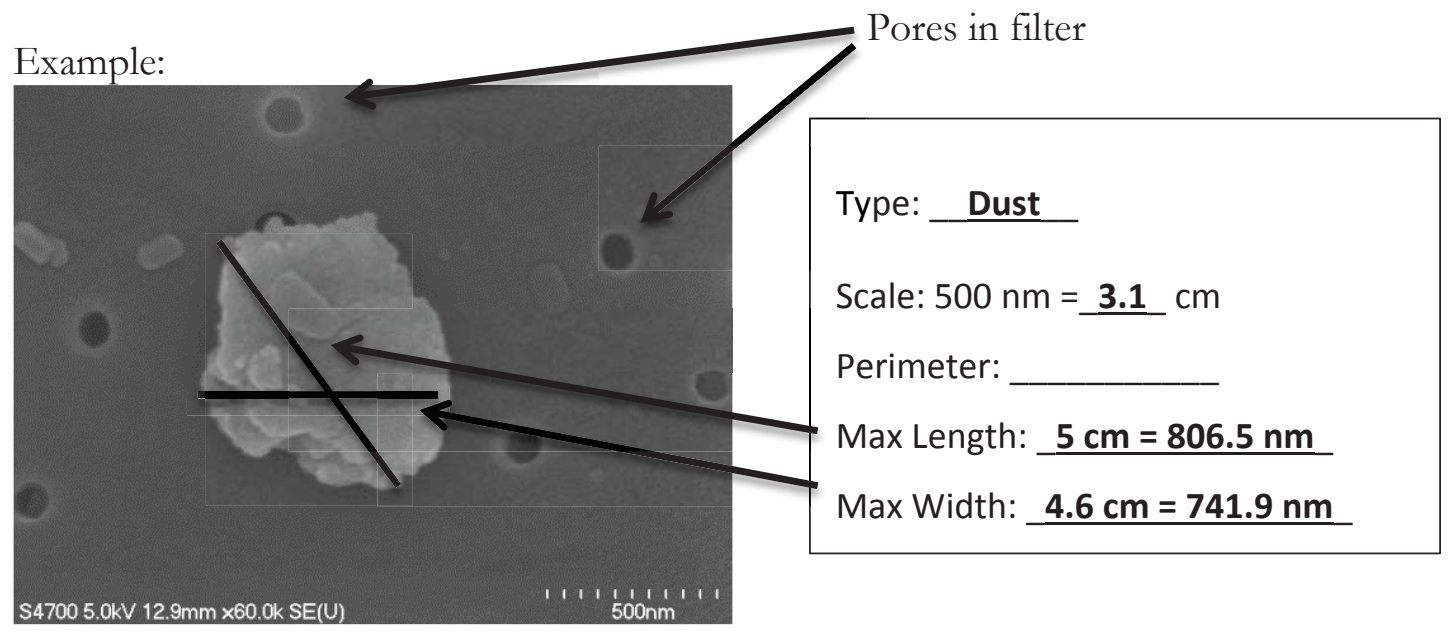

Have students measure each particle indicated in their packet using the following directions:

1. Measure the scale (ex, $500 \mathrm{~nm}=$ $\mathrm{cm}$ ) on each image (not all scales are the same)

2. Carefully measure the perimeter, maximum length and maximum width.

3. Convert measurements to nanometers using the conversion from the scale.

4. Convert measurements so they all have the same units. $1000 \mathrm{~nm}=1 \mu \mathrm{m}$ 
* Answers provided have been generated by ImageJ (computer program). The students' answers may not be exactly the same, but should be close. *

Answers are provided:
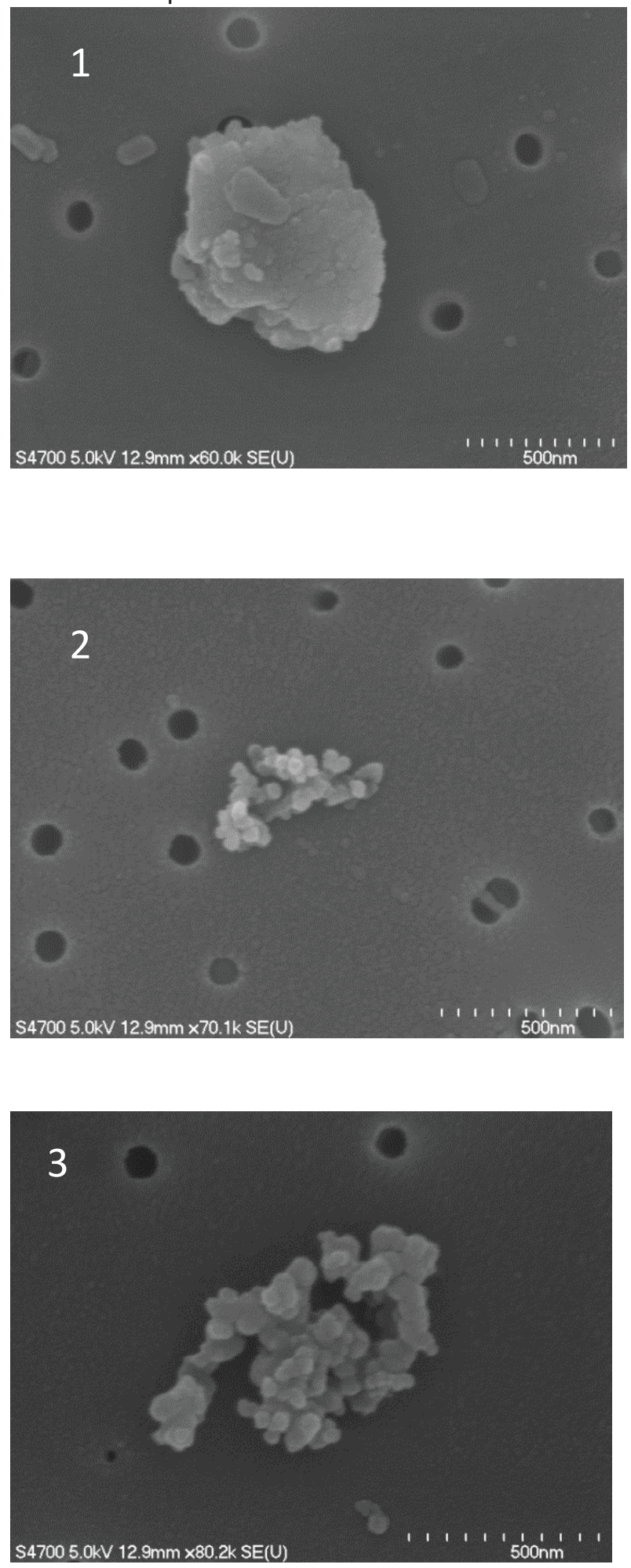

Type: Dust

Scale: $500 \mathrm{~nm}=$ $\mathrm{cm}$

Perimeter: $\mathbf{2 9 7 2} \mathbf{n m}=\mathbf{2} .972 \boldsymbol{\mu m}$

Max Length: $\_894 \mathrm{~nm}=0.894 \mu \mathrm{m}$

Max Width: $721 \mathrm{~nm}=0.721 \mu \mathrm{m}$

Type: Soot

Scale: $500 \mathrm{~nm}=$ $\mathrm{cm}$

Perimeter: $2335 \mathrm{~nm}$

Max Length: $\_546 \mathrm{~nm}$

Max Width: $298 \mathrm{~nm}$

Type:

Scale: $500 \mathrm{~nm}=$ $\mathrm{cm}$

Perimeter: $\mathbf{4 7 7 0} \mathrm{nm}$

Max Length: $914 \mathrm{~nm}$

Max Width: 505 nm 

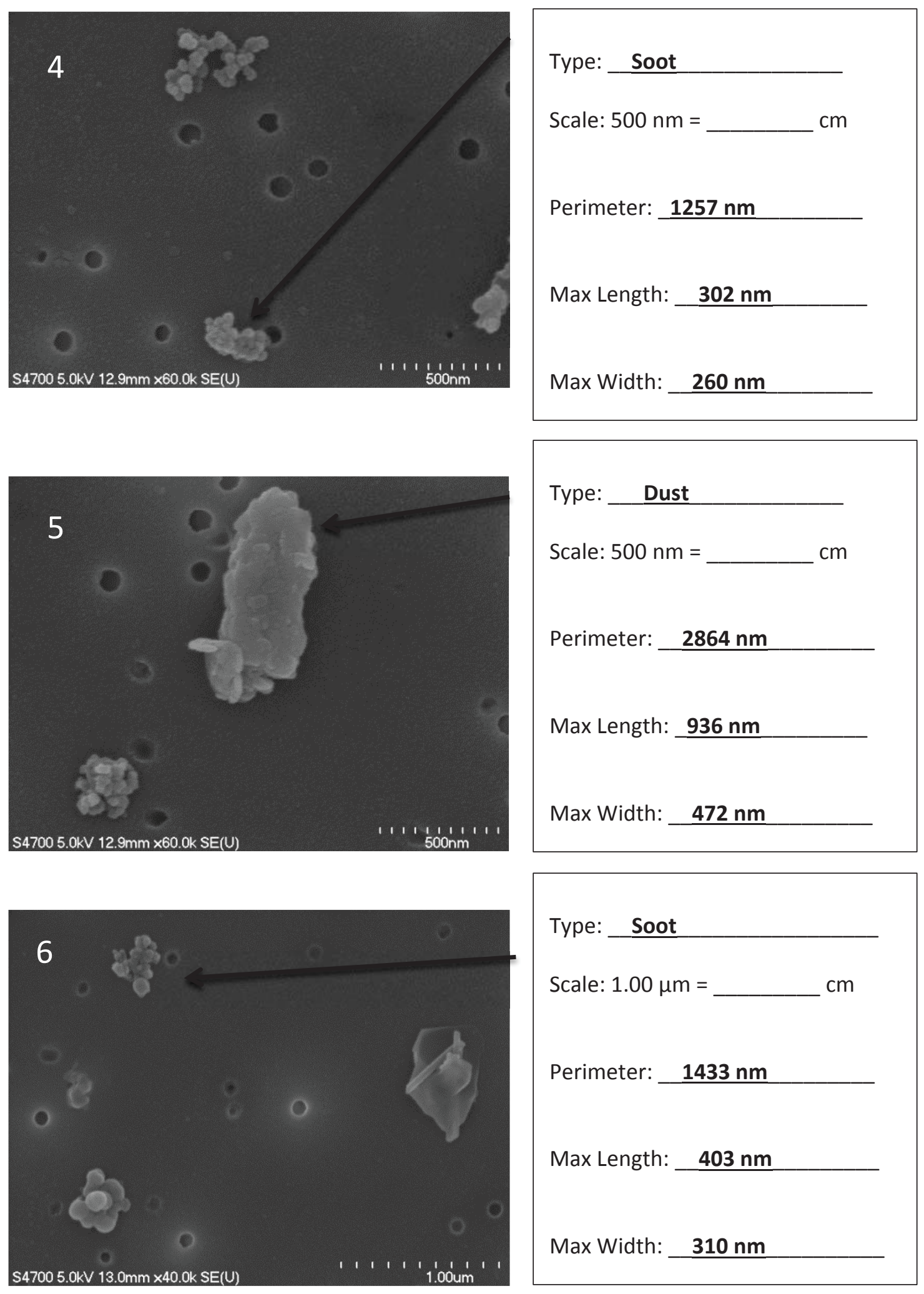

Type: __oot
Scale: $1.00 \mu \mathrm{m}=\ldots \mathrm{cm}$
Perimeter: $1433 \mathrm{~nm}$
Max Length: $\_03 \mathrm{~nm}$
Max Width: $\_310 \mathrm{~nm}$



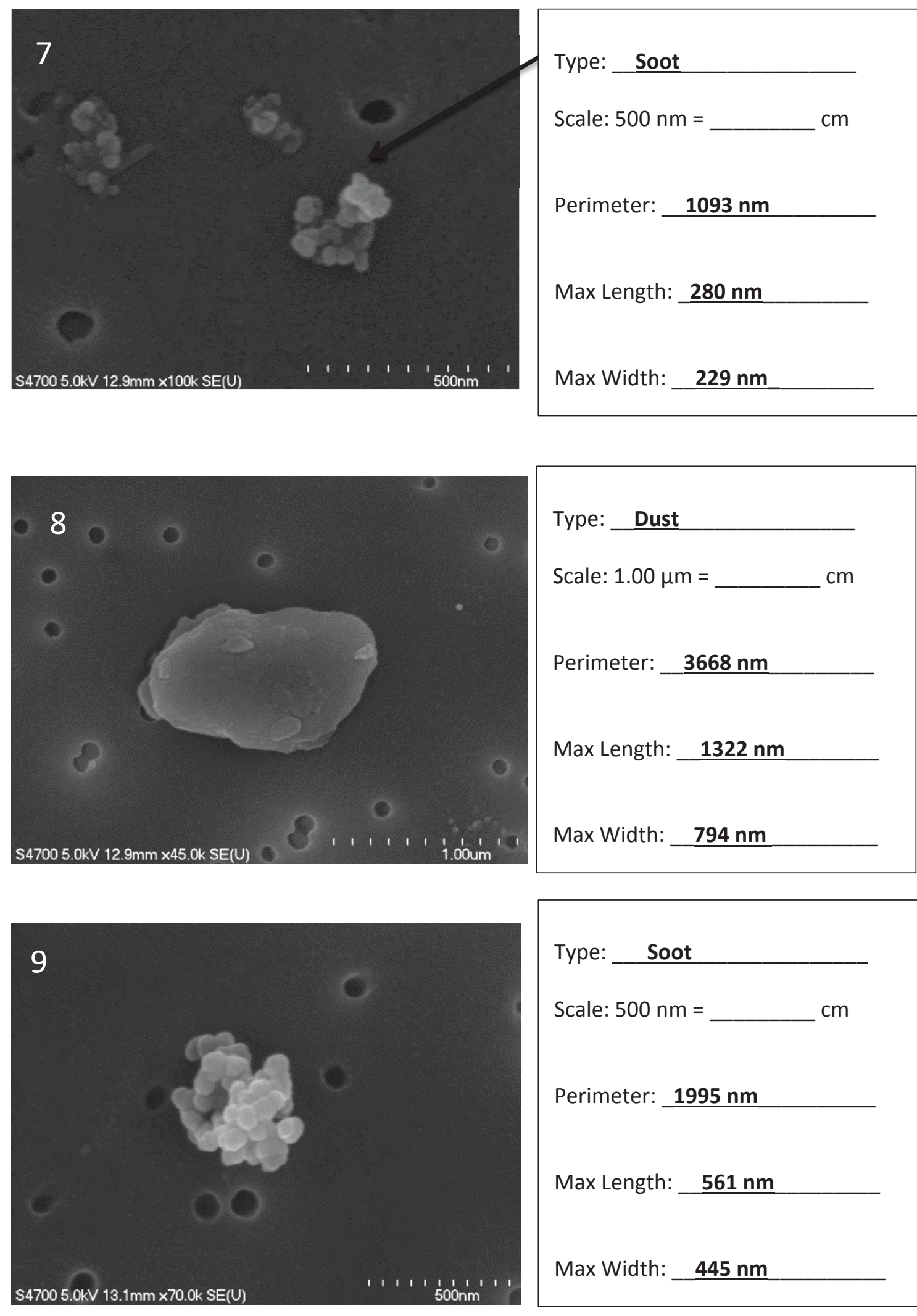

Type: ___ Soot
Scale: $500 \mathrm{~nm}=\ldots \_\mathrm{cm}$
Perimeter: $1995 \mathrm{~nm}$
Max Length: $\_561 \mathrm{~nm}$
Max Width: $\_445 \mathrm{~nm}$




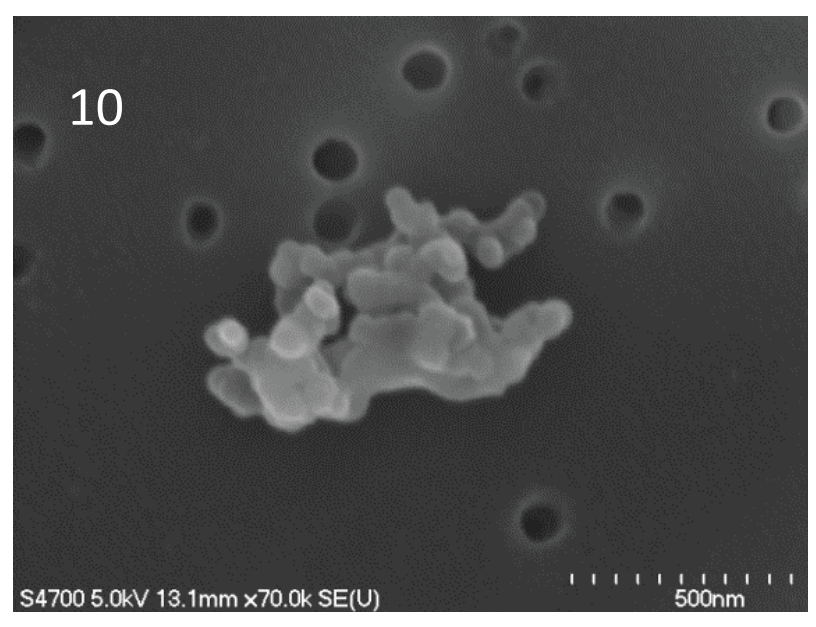

Type: Soot

Scale: $500 \mathrm{~nm}=$ $\mathrm{cm}$

Perimeter: $3936 \mathrm{~nm}$

Max Length: $\_\mathbf{8 8 1} \mathrm{nm}$

Max Width: $\quad 515 \mathrm{~nm}$

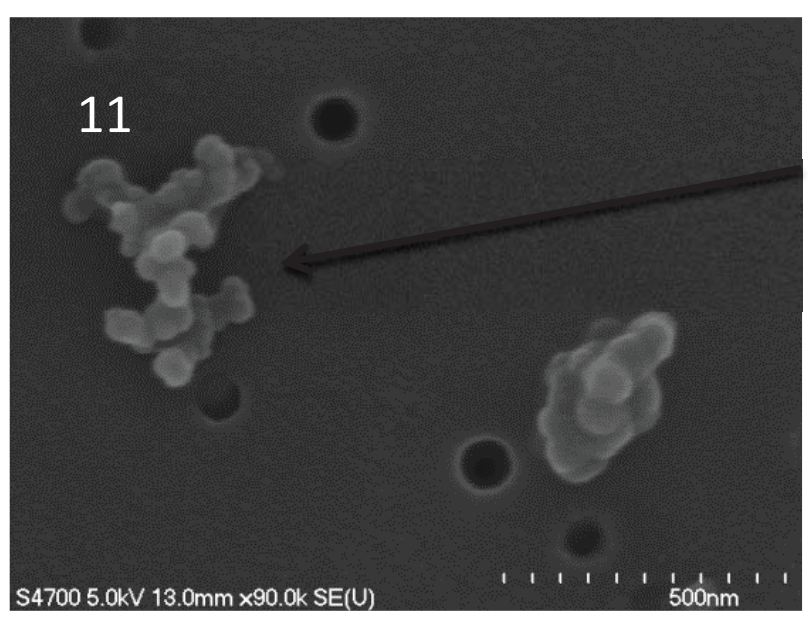

Type: Soot

Scale: $500 \mathrm{~nm}=$ $\mathrm{cm}$

Perimeter: $\quad 2092$ nm

Max Length: $459 \mathrm{~nm}$

Max Width: $\_374 \mathrm{~nm}$

Type: ___ Soot

Scale: $500 \mathrm{~nm}=$ $\mathrm{cm}$

Perimeter: $\mathbf{1 1 4 5} \mathrm{nm}$

Max Length: $295 \mathrm{~nm}$

Max Width: $\_254 \mathrm{~nm}$ 
Questions:

1. Of the soot particles, which ones would you consider "round"?

$4,7,9,12$

2. What causes the particles to become more round?

Aging in the atmosphere, more time in atmosphere leads to more compaction

3. Where do you think the dust particles came from?

Desert regions, Africa, gets blown and caught in a wind belt and carried northward

4. How do you think you would be able to determine the source of the dust particles? Check the date of the sample, check weather patterns for that day and previous couple days, any severe weather event (i.e.: dust/sand storm)

5. Based on your notes, tell the "story" of particles 2, 9, 11, and 12.

(answers may vary, but should include the following)

2. smaller soot particle, parts are compacted indicating it travelled some in the atmosphere, not very aged, not very round

9. smaller soot particle, compacted and round, aged in atmosphere due to long range transport

11. small soot particle, elongated and not round, has not been in the atmosphere long

12. very small soot particle, compact and round, tra velled long period of time/distance in atmosphere 


\section{Teaching Notes - Chemistry of Aerosols}

\section{Overview:}

In this lesson, students will be exposed to real scientific data gathered on Pico Mountain and analyzed back in the lab at MTU. Scientists collect aerosols using the high volume samplers. The first video students will watch explains how the samples work and what an aerosol collection on the filter looks like. The second video illustrates how the samples are analyzed in the lab. After the videos, students will analyze the data collected in the lab and determine where the aerosols may have travelled from. Some research team members have the task of modeling and extrapolating back to determine weather patterns and events. The graphs were created by Simeon Schum, MTU.

\section{The Lesson:}

To start the day's lesson, use the PowerPoint provided:

- Slide 1 - Photo showing aerosols on a filter from a high volume sampler

- Slide 2 - Video questions for students to answer (Pico Video High Volume Sampler)

- Slide 3 - Link to the high volume sampler video (approximately 7 minutes)

- Slide 4 - Video questions for students to answer (Pico Video OC/EC)

- Slide 5 - Link to the OC/EC video (approximately 10 minutes)

- Slide 6 - Today's tasks

- Slide 7 - Websites to use to investigate weather patterns and events

- Slide 8-Graphic illustrating global wind patterns

- Slides 9-10 - Examples of analyzed data

- Slide 11 - Explanation of event and non-event

Aerosols are collected in samplers located in the caldera of Pico Mountain. There are 4 samplers, each sampler runs for 24 hours and filters are changed every 3-4 days. The filters are carefully packaged, kept cold and brought back to MTU to be analyzed in the lab. The aerosols are measured in micrograms per cubic meter of air. The graphs provided are the end result of the analysis. Students will analyze these graphs for events and use weather data to determine were the aerosols could have travelled from. Aerosol particles can take several days to reach Pico, depending on the source of the aerosol. Keep in mind, these aerosol particles are from the free troposphere and, therefore, are not local to Pico.

Peaks in data indicate high levels of organic carbon or elemental carbon. For example, the peak shown on the graph for July 3, 2013 originally was thought to be dust when we saw the color on the filter. However, upon analysis it was determined to be organic carbon, possibly from the forest fires occurring in Canada at that time. By examining the fire event website and weather patterns, students should be able to come to that same conclusion. This is relevant to students due to the fact that most of these aerosols are coming from North America. 
Other scientists on the research team analyze the specific types of carbon molecules collected on the filters. They use other pieces of equipment and determine the number of carbon atoms in the chain and narrow down further what the aerosol particles are.

\section{Answers:}

All are events except the first September graph (Sept $9-12)$. July event was most likely due to forest fires occurring in Canada. 


\section{Teaching Notes - Scattering and Absorption}

\section{Overview:}

In this lesson, students will explore how aerosols absorb and scatter light energy. The video for this lesson is a demonstration by Bill Nye. This demo can also be done in the classroom with a large water container, air pump, and a match. Bill Nye shows how, with soot, clouds are whiter and easier to see. With soot particles, there are more surfaces for water to condense on. These particles are called cloud condensation nuclei (CCN). White objects, such as clouds and some aerosol particles scatter and reflect light energy which leads to cooling of the atmosphere. Other aerosols could be darker in color and therefore absorb light energy. This causes warming of the atmosphere. In general, aerosols tend to have a cooling effect (they mask the warming).

The experiment in this lesson can be done several ways. If students are familiar and experienced with inquiry, a list of materials can be given and then students would write their own procedures and carry out the experiment. For classrooms that do not have experience with inquiry, the materials and procedures can be provided for the experiment. Any degree of inquiry could be done with this experiment.

\section{The Lesson:}

To start the day's lesson, use the provided PowerPoint:

- Slide 1 - Photo of pollution layer just above the clouds at sunset

- Slides 2-4 - Students take notes on scattering, absorption, albedo and light energy

- Slide 5 - Questions for Bill Nye video

- Slide 6 - Link to Bill Nye video

- Slide 7 - Intro to experiment (students will most likely answer by saying a white shirt either by experience or knowing that white reflects and black absorbs)

- Slide 8-Basic overview of experiment

- Slide 9 - Alternate experiment (open inquiry)

- Slide 10 - Lab report assignment

If students are following a set of procedures, allow them to start on the experiment once they understand the directions and have materials. If students are designing their own experiment, have them write up their procedures first before they conduct the experiment. Check to make sure their experiment will test the difference between pure snow or ice and snow or ice with soot. Students should see that the snow or ice with soot warms faster and therefore melts quicker. This is due to the dark color soot absorbing the light energy and transferring that heat to the snow or ice.

The Bill Nye video illustrates how aerosol particles can cause a cooling effect by the presence of clouds. The experiment the students conduct illustrates how aerosol particles can warm the atmosphere. In this case, the particles do not become CCN. 


\section{Materials Needed:}

- Snow or crushed ice

- Soot

- Thermometers (2 per group)

- Light source (lamp or bright window)

- Tray to hold snow (2 per group)

- Scale

\section{Example Procedure:}

1. Place snow or crushed ice in trays (equal amount in each tray)

2. In one tray, mix in soot

3. Place trays under light source (equal distance from light)

4. Take beginning temperature and record in data table

5. Turn on light source and begin taking temperature measurements every 2 minutes and record in data table

6. Continue for 30 minutes

7. Make observations between temperature readings and record on lab handout 


\section{Teaching Notes - Pico Project Video}

\section{Overview:}

The purpose of this lesson is to show students what scientists look like, where they work, and what they do. They will answer questions from the video and then reflect on their work from this unit. As they compare what they did to what scientists do, they should start to gain an understanding that what they did is very similar. Another purpose is to promote collaboration and its importance. Scientists cannot do it all by themselves. Many work in teams from the same university and some have team members from multiple universities (such is the case with the Pico Project).

\section{The Lesson:}

- Handout the video questions

- Show the video labeled "Pico Elaborate". This is in two parts and depending on time, they could be shown in one day or two. Part 1 goes with questions 1-10 and part 2 includes questions 10-13.

- Discuss what science is, the importance of collaboration, and how the students' work relates to scientists' work.

\section{Answers - Video Questions:}

1. Who first contacted Prof. Paulo Fialho and when?

\section{Richard Honrath, 1998}

2. What was Drs. Mazzoleni's relationship with Richard?

They were both hired by Dr. Honrath and included in the atmospheric science work he was doing

3. Where are other atmospheric stations located? Why are the stations on Pico and Mauna Loa unique?

Pico and Mauna Loa are unique in the fact that they are the only two atmospheric research stations located in the middle of an ocean, away from the continent. The other stations are located on land.

4. When did the equipment arrive and how did it get to the top of the mountain?

\section{In 2001 by U.S. Air Force cargo planes}

The station was lifted by helicopter to the top of the mountain.

5. In what year was the station installed?

2001

6. Based on what you see in the video, why doesn't the team gather data in the winter?

Dangerous conditions, snow and ice (mainly ice) 
7. Do scientists really use the "scientific method" as it is traditionally described?

In a way, yes - they ask questions and start to answer them by experimenting. This tends to lead to more questions and more investigations. In the end, they come up with conclusions and publish them.

8. What are the steps to get work published? How long does this take?

(Working backwards) Publish, analyze data and write paper, collect data, wait for proposal acceptance, write proposal - whole process can take 3 years from the time you come up with an idea to the time the data is published in a journal

9. Do all scientists understand everything? Do they ever have other scientists work on their projects? Why or why not?

No, they do not understand everything. Scientists become very specialized in one particular topic. That's why it is important to have other scientists with different expertise on the team. With all scientists working together on a common plan, data can be shared and conclusions can be made. (Like the elephant poem, you need to know what every person is feeling in order to get the big picture)

10. How important is collaboration? Explain.

Very important! Not everything can be done by one person, and one person cannot know everything about the project. (Answer should also include specific statements made by those in the video)

11. How did the following team members get involved in the Pico Project and what is their role:

\begin{tabular}{|l|l|l|}
\hline Scientist & How they got involved & Role in the project \\
\hline Bo Zhang & $\begin{array}{l}\text { Other project did not get } \\
\text { funding }\end{array}$ & Modeling work \\
\hline $\begin{array}{l}\text { Lynn } \\
\text { Mazzoleni }\end{array}$ & $\begin{array}{l}\text { PI (Principle Investigator) of } \\
\text { project } \\
\text { Developed the project to } \\
\text { investigate aerosols and also } \\
\text { keep Richard's memory } \\
\text { alive. }\end{array}$ & $\begin{array}{l}\text { Chemical properties of } \\
\text { aerosols }\end{array}$ \\
\hline $\begin{array}{l}\text { Claudio } \\
\text { Mazzoleni }\end{array}$ & $\begin{array}{l}\text { PI (Principle Investigator) of } \\
\text { project } \\
\text { Developed the project to } \\
\text { investigate aerosols and also } \\
\text { keep Richard's memory } \\
\text { alive. }\end{array}$ & $\begin{array}{l}\text { Physical properties of } \\
\text { aerosols }\end{array}$ \\
\hline
\end{tabular}




\begin{tabular}{|l|l|l|}
\hline Katja Dzepina & Invited by Lynn Mazzoleni & $\begin{array}{l}\text { High resolution mass } \\
\text { spectrometry } \\
\text { (determines the chemical } \\
\text { composition of the aerosols) }\end{array}$ \\
\hline Kendra Wright & $\begin{array}{l}\text { Opportunity presented itself } \\
\text { and received funding from } \\
\text { NASA }\end{array}$ & Physics and lasers \\
\hline
\end{tabular}

12. What are some of the roles other scientists have in the current project?

Analyze data, technicians, gas measurements, regional and global scale modeling, students, chemical measurements, a teacher to write lessons based on research

13. What do scientists gain from collaboration?

Examples of statements from team members: measurement data from others in order to do their job, help from professors, collaboration is everything - we can do more together and learn more, expertise from so many coming together, unique perspectives from students and other scientists around the world, dependent on each other otherwise project would not get done

Think:

14. How did what you completed in this unit relate to what actual scientists do?

Answers will vary: Perform experiments, collect data, analyze data, collaborate/work with others

15. Do you think it would be helpful to share ideas while doing experiments in class? Why or why not?

Answers will vary: Yes, see things in a different way, some things could have been missed, etc. 


\section{Teaching Notes - Evaluate}

\section{Overview:}

In this assessment, students will answer the big idea question from the beginning of the unit using the Claim-Evidence-Reasoning method. Example questions could be, "What role do aerosols play in climate change?" or "How do aerosols affect climate?" Their answer to the question is their "claim". A claim should be supported by evidence from past lessons and activities. Evidence can just be listed, and should not be explained. Evidence can come from data, notes, video statements, etc. In the reasoning section, students explain how their evidence relates to their claim. At this point they are providing reasoning as to why their evidence supports their claim. This type of writing assignment takes time to understand. Modeling the steps is necessary the first few times students answer questions this way. If students are familiar with this procedure, give them the rubric and let them begin. Most importantly, students need to understand that their interpretations and conclusions are based on the evidence they have at the time and that their conclusions can change. When more data become available, scientists analyze these data and can change their conclusions.

\section{The Lesson:}

- Explain Claim-Evidence-Reasoning (CER) method of answering scientific questions

- Discuss the grading rubric and make sure each student has a copy

- If needed, model CER with students and guide them in making their claim and help them list evidence

Make sure students understand that aerosols are short lived and therefore affect regional climates, NOT on a global scale. Below are examples and non-examples for claims and evidence. The "reasoning" section should be in paragraphs and must explain the evidence and how it relates to the claim. For example, if a student listed "some aerosols provide a cooling effect" as a piece of evidence, they would explain how the aerosols cool the atmosphere (become CCN, more surfaces for water to condense on, clouds are visibly whiter and reflect the light energy which causes cooling.)

- Claim examples:

- Aerosols affect the local climate by producing more clouds, therefore increasing the albedo and causing cooling.

- Aerosols affect the local climate by absorbing incoming solar radiation due to their dark color and causing warming.

- Claim non-examples:

- Aerosols have no effect on climate.

- Aerosols in the form of dust can come from Africa.

- Evidence examples:

- Secondary organic aerosols (SOAs) change in the atmosphere as they travel 
- Some aerosols provide a cooling effect

- Some aerosols provide a warming effect

- Soot comes from organic sources, such as forest fires

- Aerosol particles can become CCN

- SOAs are short lived

- Evidence non-examples:

- Pico is located in the North Atlantic

- Pico Mountain in an inactive stratovolcano

- The Azores is an archipelago

The attached rubric can be used as is, or edited for your own grading. Included on the rubric are sections for posters, presentations and citations. These can be omitted if time does not allow for it. 


\section{Pico Project CER Rubric}

\begin{tabular}{|c|c|c|c|c|}
\hline & 5 points & 3 points & 1 point & 0 points \\
\hline Claim & $\begin{array}{l}\text { Clearly provides a } \\
\text { correct answer that } \\
\text { can be supported } \\
\text { with evidence from } \\
\text { lessons and research }\end{array}$ & $\begin{array}{l}\text { Provides an } \\
\text { answer that can } \\
\text { be supported }\end{array}$ & $\begin{array}{l}\text { Provides an } \\
\text { answer that is } \\
\text { vague and } \\
\text { cannot be } \\
\text { supported }\end{array}$ & No claim given \\
\hline Evidence & $\begin{array}{l}\text { Provides } 5 \text { pieces of } \\
\text { valid evidence from } \\
\text { lessons and research } \\
\text { that relate to claim }\end{array}$ & $\begin{array}{l}\text { Provides } 3-4 \\
\text { pieces of valid } \\
\text { evidence from } \\
\text { lessons and } \\
\text { research that } \\
\text { relate to claim }\end{array}$ & $\begin{array}{l}\text { Provides 1-2 } \\
\text { pieces of } \\
\text { evidence from } \\
\text { lessons and } \\
\text { research that } \\
\text { relate to claim; } \\
\text { OR provides 3- } \\
4 \text { pieces of } \\
\text { evidence that do } \\
\text { not relate to } \\
\text { claim }\end{array}$ & $\begin{array}{l}\text { No evidence } \\
\text { given; OR 1-2 } \\
\text { pieces of } \\
\text { evidence is } \\
\text { given that do } \\
\text { not relate to } \\
\text { claim }\end{array}$ \\
\hline Reasoning & $\begin{array}{l}\text { Provides clear } \\
\text { explanation linking } \\
\text { all pieces of } \\
\text { evidence to claim }\end{array}$ & $\begin{array}{l}\text { Provides clear } \\
\text { explanation } \\
\text { linking some } \\
\text { evidence to } \\
\text { claim }\end{array}$ & $\begin{array}{l}\text { Provides } \\
\text { explanation for } \\
\text { some evidence } \\
\text { but not linking } \\
\text { to claim }\end{array}$ & $\begin{array}{l}\text { No explanation } \\
\text { is given }\end{array}$ \\
\hline Poster & $\begin{array}{l}\text { Poster is complete } \\
\text { with "Claim, } \\
\text { Evidence and } \\
\text { Reasoning", includes } \\
\text { drawings and is neat } \\
\text { and colorful }\end{array}$ & $\begin{array}{l}\text { Poster includes } \\
\text { "Claim, } \\
\text { Evidence and } \\
\text { Reasoning" and } \\
\text { is neat }\end{array}$ & $\begin{array}{l}\text { Poster only has } \\
2 \text { of the } 3 \text { CER } \\
\text { components }\end{array}$ & $\begin{array}{l}\text { Poster does not } \\
\text { contain the } \\
\text { required } \\
\text { information }\end{array}$ \\
\hline Presentation & $\begin{array}{l}\text { Given slow, clear } \\
\text { and includes } \\
\text { explaining all } \\
\text { components of the } \\
\text { CER as well as } \\
\text { describing the } \\
\text { drawings }\end{array}$ & $\begin{array}{l}\text { Given slow, } \\
\text { clear and } \\
\text { includes } \\
\text { explaining all } \\
\text { components of } \\
\text { the CER }\end{array}$ & $\begin{array}{l}\text { Given excluding } \\
\text { one or more } \\
\text { components of } \\
\text { the CER }\end{array}$ & $\begin{array}{l}\text { Not given; OR } \\
\text { given without } \\
\text { including any } \\
\text { components of } \\
\text { the CER }\end{array}$ \\
\hline Citations & $\begin{array}{l}4-5 \text { citations are } \\
\text { given in APA } \\
\text { format }\end{array}$ & $\begin{array}{l}\text { 2-3 citations are } \\
\text { given in APA } \\
\text { format; OR 3-5 } \\
\text { citations are } \\
\text { given in the } \\
\text { incorrect format }\end{array}$ & $\begin{array}{l}\text { 1-2 citations are } \\
\text { given in APA } \\
\text { format; OR 2-3 } \\
\text { citations are } \\
\text { given in the } \\
\text { incorrect format }\end{array}$ & $\begin{array}{l}0 \text { citations are } \\
\text { given }\end{array}$ \\
\hline
\end{tabular}




\section{APPENDIX C: STUDENT HANDOUTS \\ Pico Project: Introduction}

Directions: Use the internet to find answers and as much information as you can about these questions. Sites to avoid: about.com, ask.com, etc.

1. Find the elevation of Pico Mountain. (Careful - this is not in the United States!)

2. Where is Pico Mountain located? (be specific)

3. Describe the mountain.

4. What is the boundary layer in terms of the atmosphere?

5. What is the free troposphere?

6. What is the altitude of the marine boundary layer?

Based on the above answers: Why is Pico Mountain a good place to study the atmosphere? 


\section{Classifying and Measuring Aerosol Particles}

Directions: Using the directions provided, classify each particle as either mineral dust or soot. Next, measure each particle using a ruler. Make sure you measure the scale so you know the conversion factor.

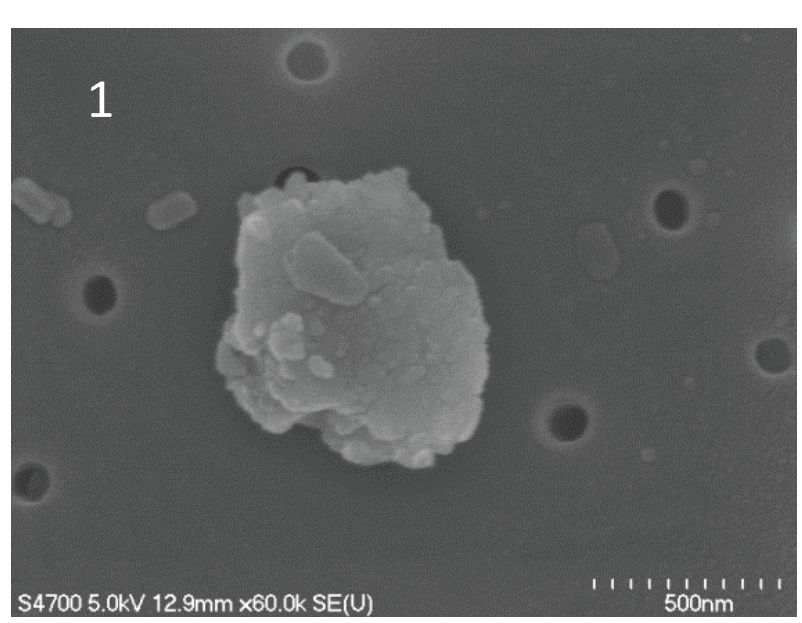

Type:

Scale: $500 \mathrm{~nm}=$ $\mathrm{cm}$

Perimeter:

Max Length:

Max Width:

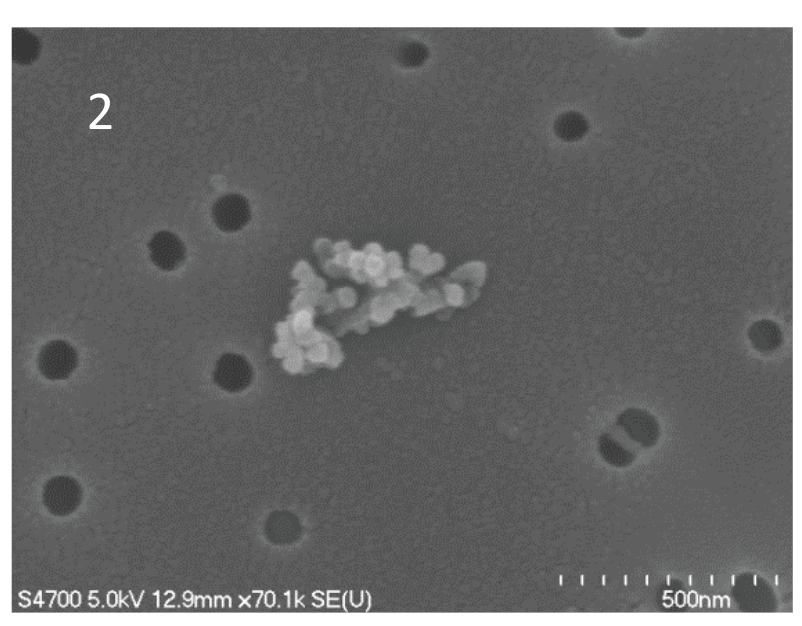

Type:

Scale: $500 \mathrm{~nm}=$ $\mathrm{cm}$

Perimeter:

Max Length:

Max Width: 


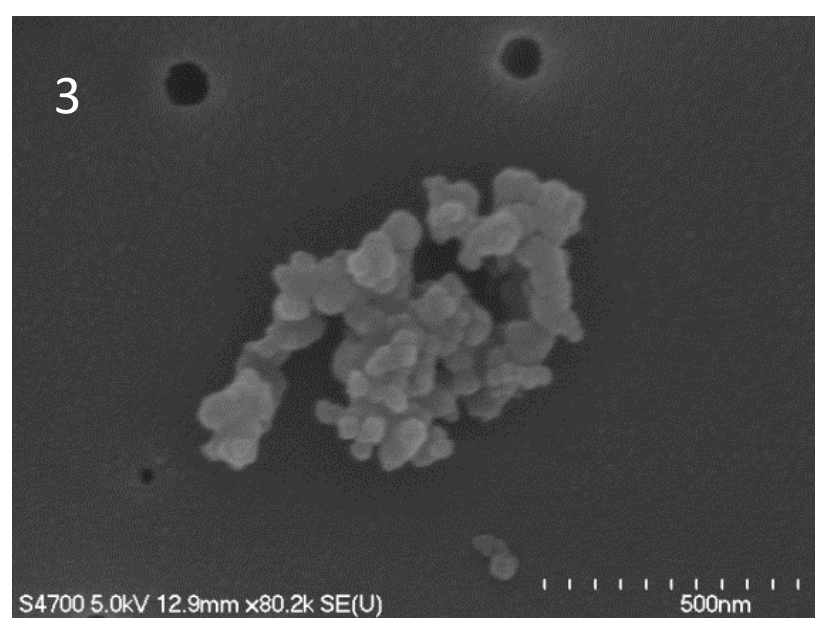

Type:

Scale: $500 \mathrm{~nm}=$ $\mathrm{cm}$

Perimeter:

Max Length:

Max Width:

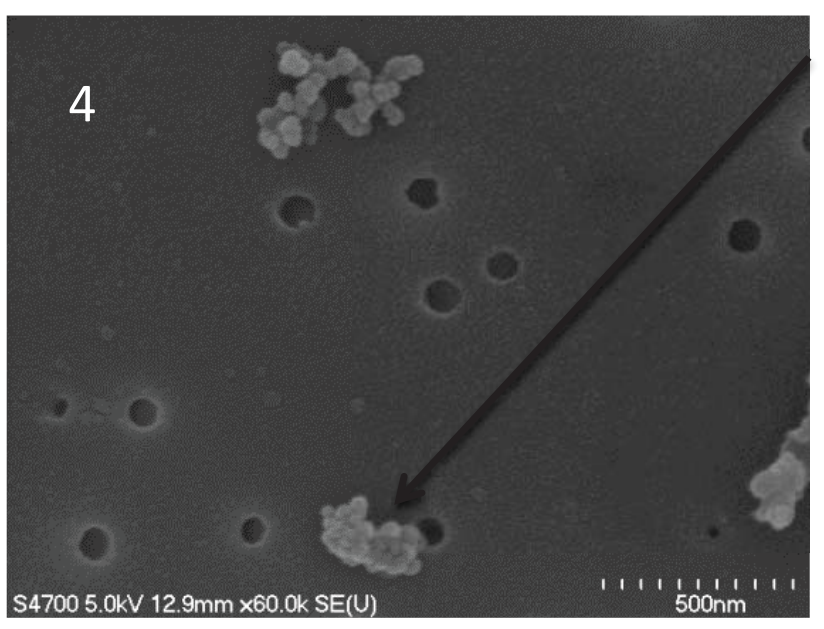

Type:

Scale: $500 \mathrm{~nm}=$ $\mathrm{cm}$

Perimeter:

Max Length:

Max Width:

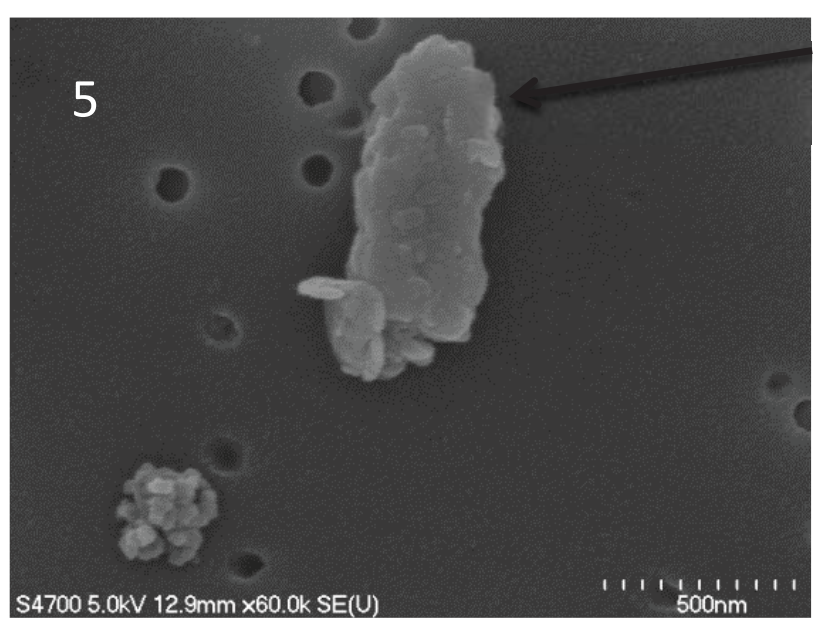

Type:

Scale: $500 \mathrm{~nm}=$ $\mathrm{cm}$

Perimeter:

Max Length:

Max Width: 

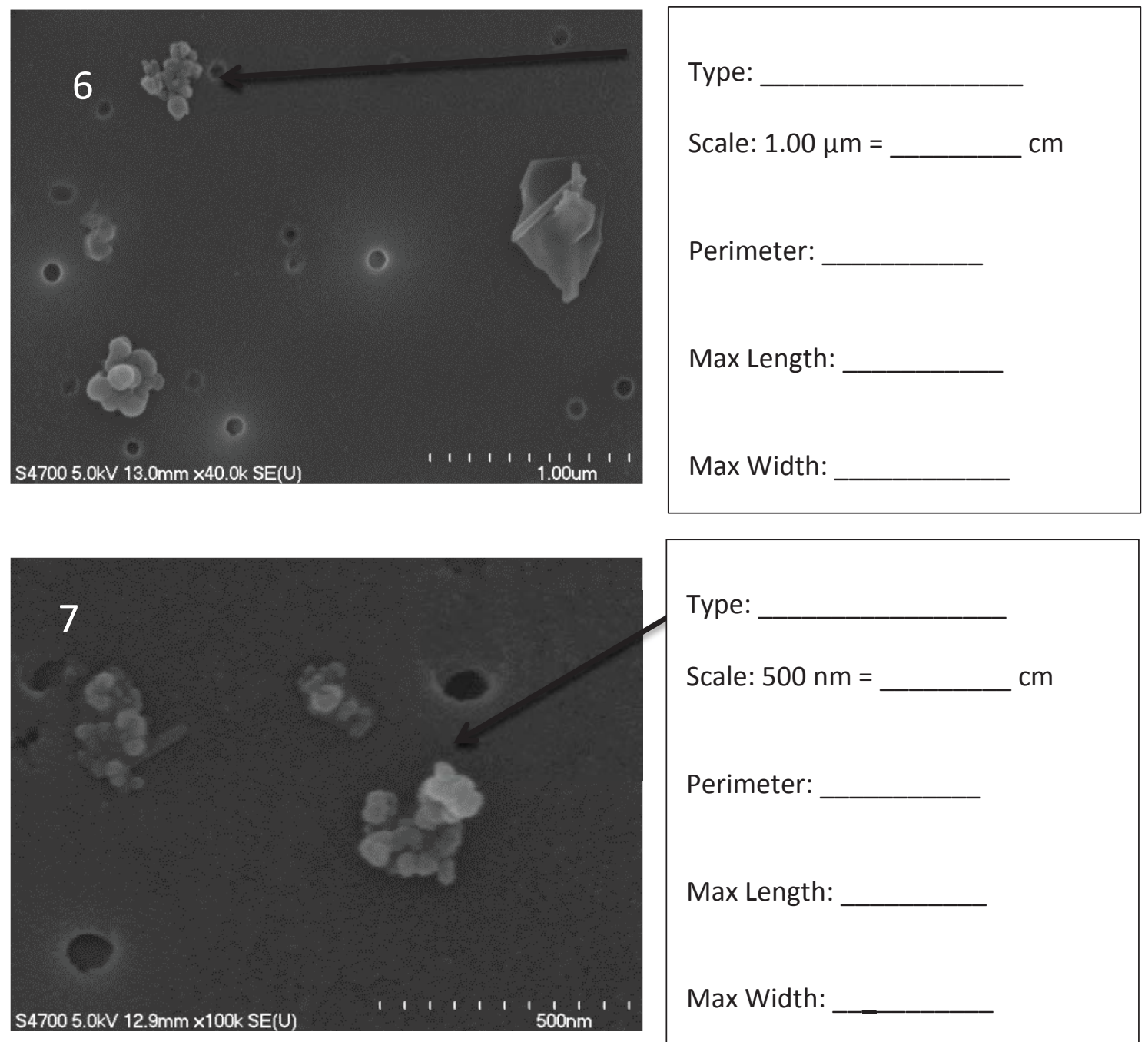

Type:

Scale: $500 \mathrm{~nm}$ = $\mathrm{cm}$

Perimeter:

Max Length:

Max Width:

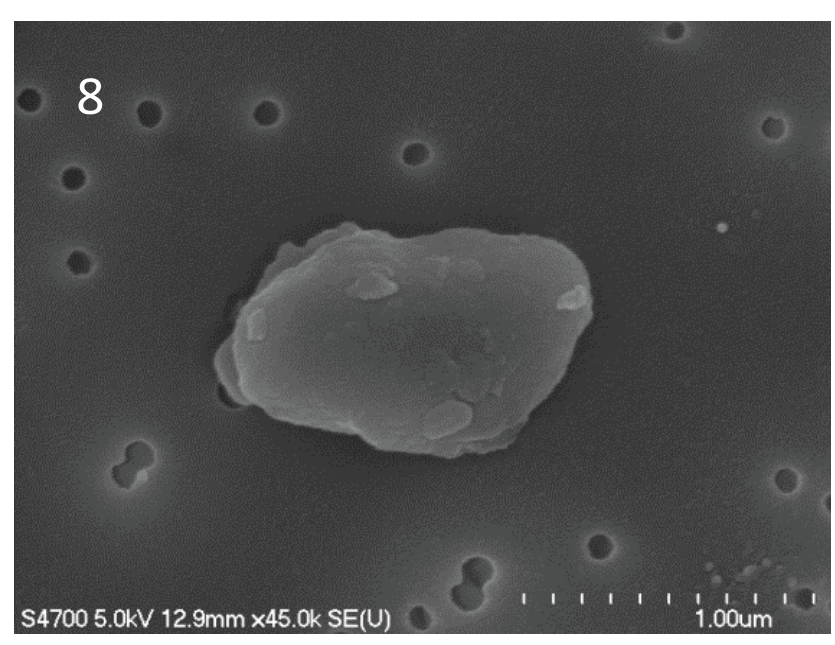

Type: $\_$
Scale: $1.00 \mu \mathrm{m}=\ldots$
Perimeter:
Max Length:
Max Width:




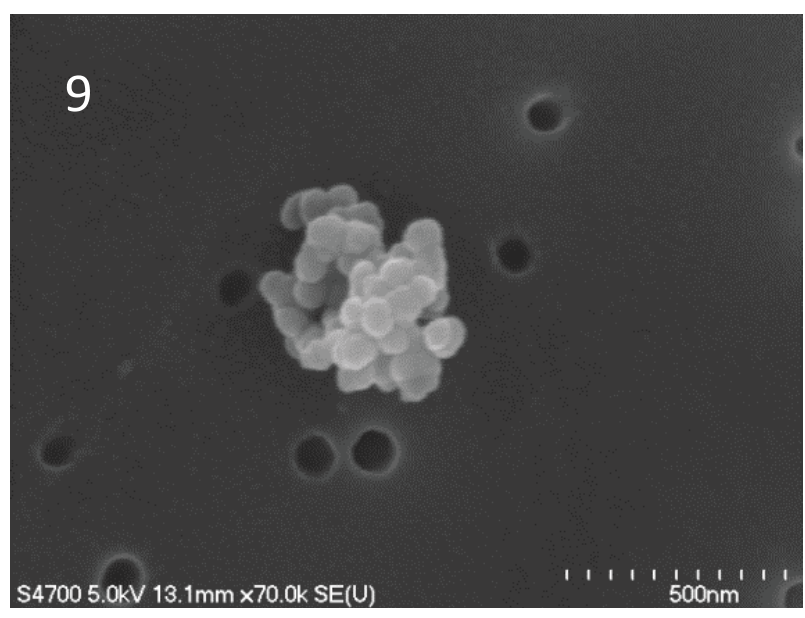

Type:

Scale: $500 \mathrm{~nm}=$ $\mathrm{cm}$

Perimeter:

Max Length:

Max Width:

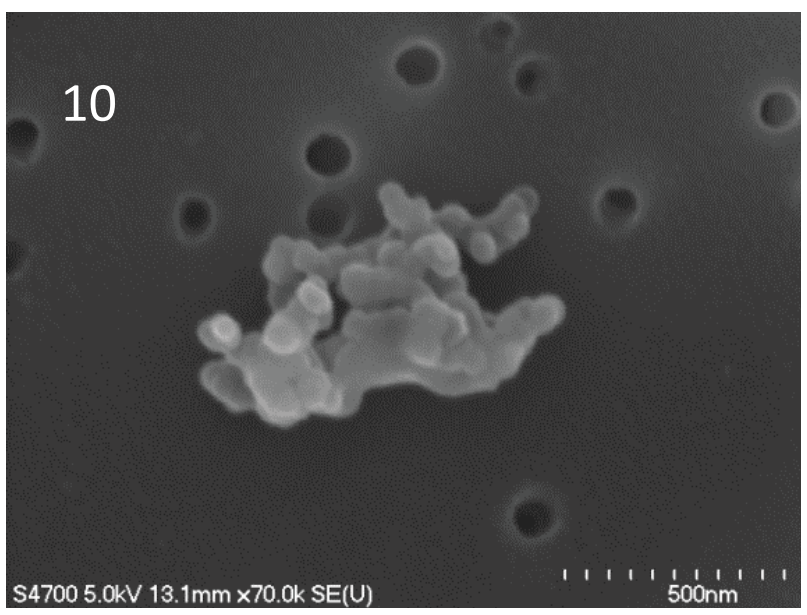

Type:

Scale: $500 \mathrm{~nm}=$ $\mathrm{cm}$

Perimeter:

Max Length:

Max Width:

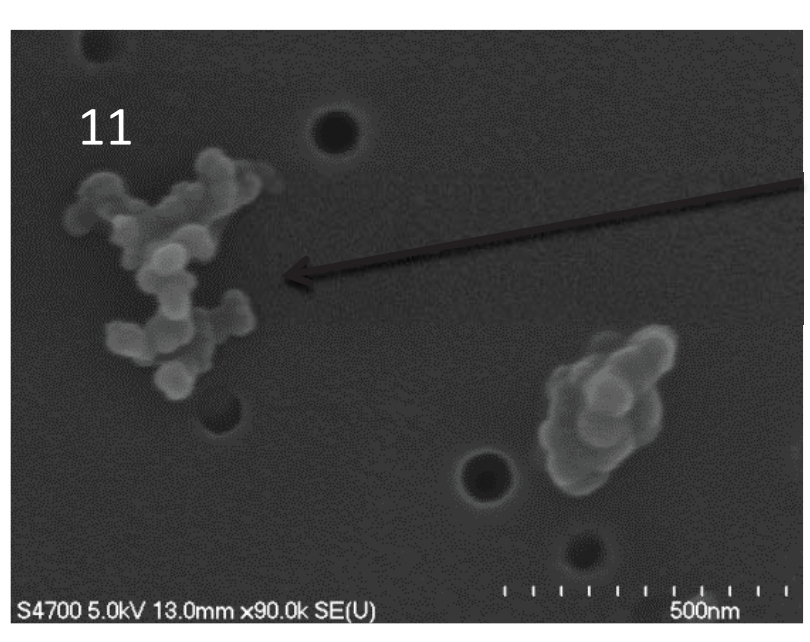

Type:

Scale: $500 \mathrm{~nm}=$ $\mathrm{cm}$

Perimeter:

Max Length:

Max Width: 

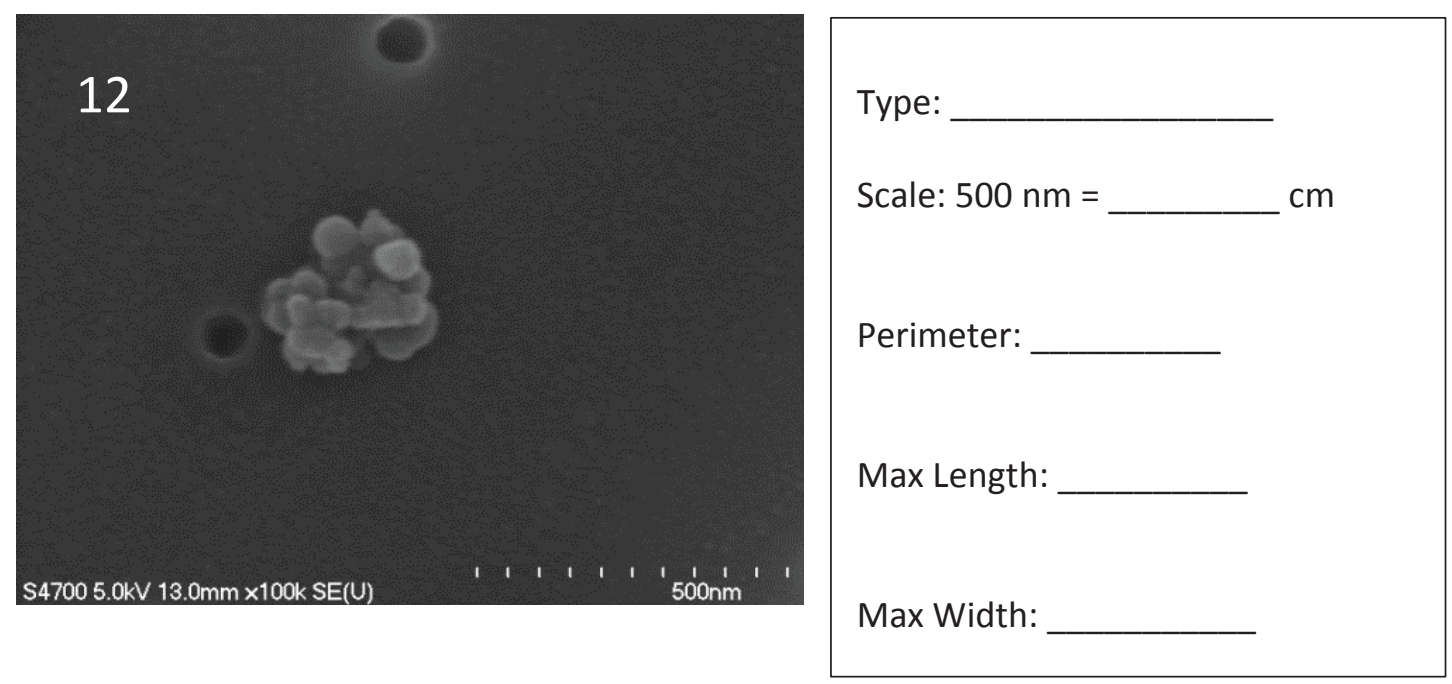

Questions:

3. Of the soot particles, which ones would you consider "round"?

4. What causes the particles to become more round?

5. Where do you think the dust particles came from?

6. How do you think you would be able to determine the source of the dust particles?

7. Based on your notes, tell the "story" of particles 2, 9, 11, and 12.

2.

9.

11.

12. 


\section{Chemistry of Aerosols}

\section{Directions:}

Examine and analyze the OC/EC data from various dates. Label each as an event or non-event. If the graph indicates an event, use weather data to determine which land mass the aerosol particles could have travelled from. Also research possible events that could have led to high levels of organic carbon in the free troposphere and list them next to the graph.
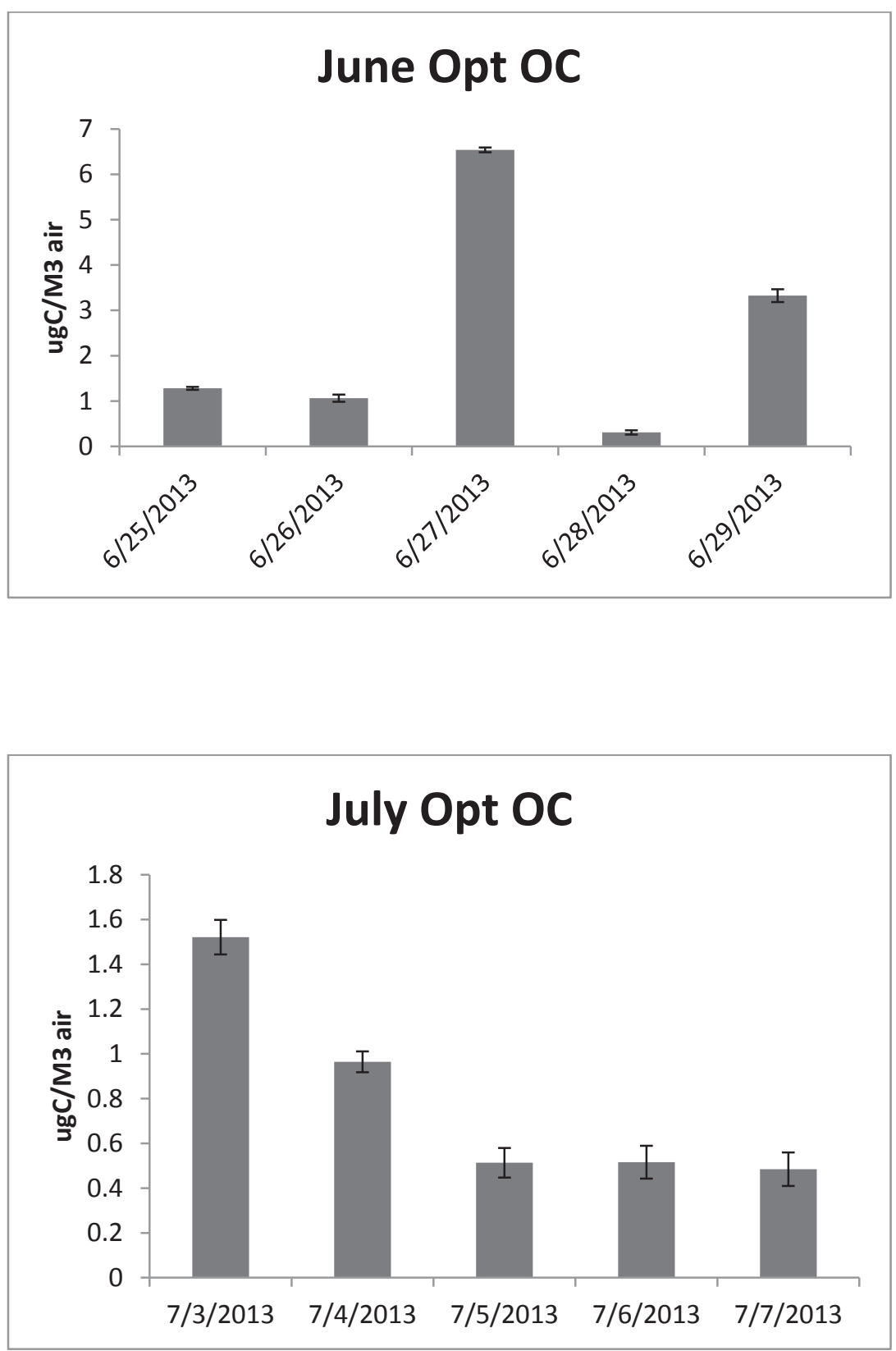

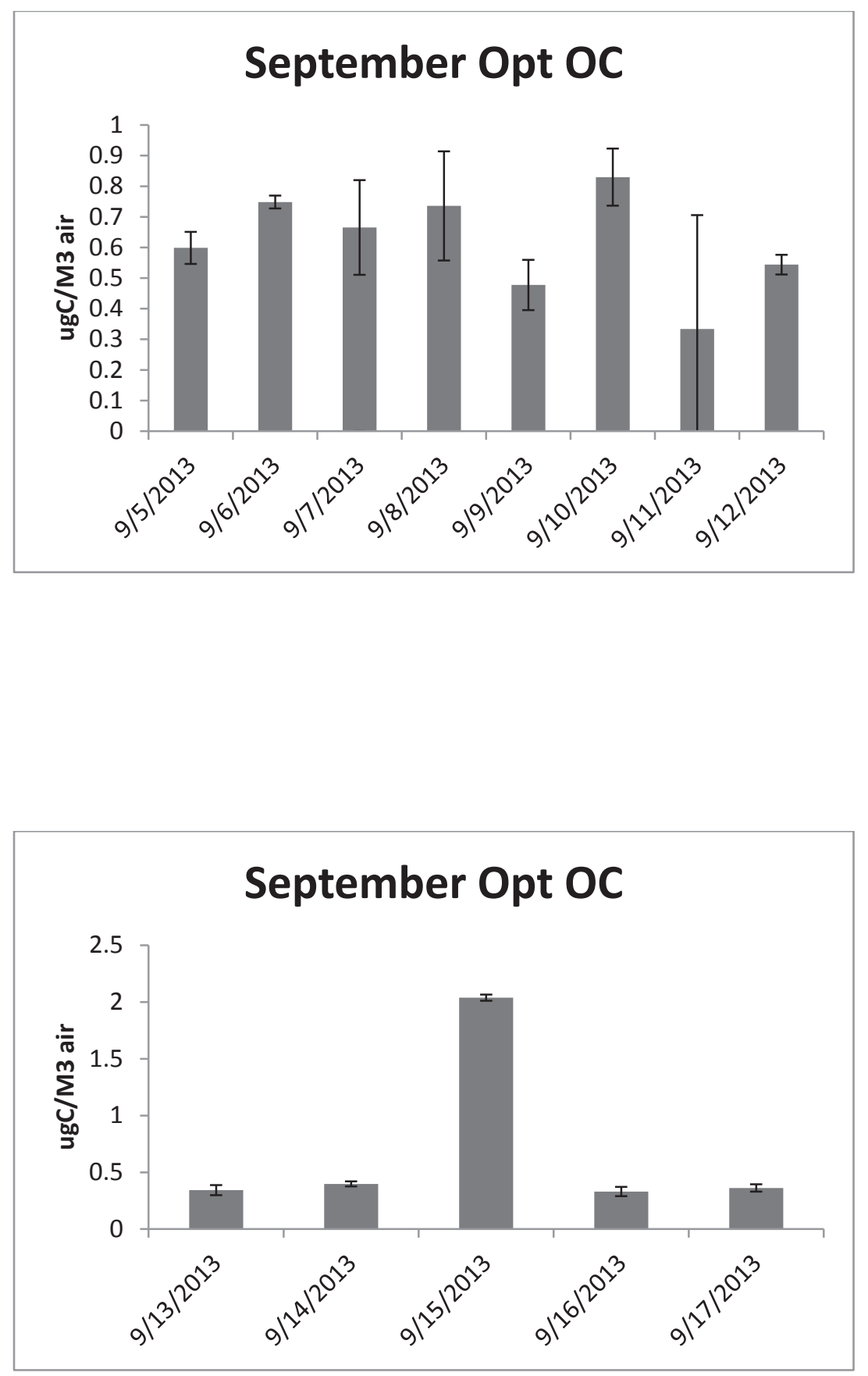


\section{Scattering and Absorption}

Directions: You will be conducting an experiment comparing pure crushed ice or snow to crushed ice or snow with soot. Make detailed observations and measurements. Following the experiment, you will be writing a lab report.

\section{Materials:}

- 2 Trays

- Crushed ice or snow

- 2 Thermometers

- Light source

- Soot

- Data table

- Stop watch, watch or clock

- Scale

\section{Procedure:}

1. Obtain required materials

2. Place equal amounts of crushed ice or snow in each tray (use the scale)

3. In one tray, mix in soot

4. Place both trays under the light source

5. Take temperature measurements of both samples before turning the lamp on

6. Record measurements in the data table, along with physical observations (Time 0:00)

7. Turn lamp on and begin timing

8. Take temperature measurements every 2 minutes and record in the data table

9. Continue for 30 minutes

10. Record physical observations between temperature measurements 
Data Table:

\begin{tabular}{|c|c|c|c|}
\hline $\begin{array}{c}\text { Time } \\
\text { (in } \\
\text { minutes) }\end{array}$ & $\begin{array}{c}\text { Temperature } \\
\text { Without Soot (in } \\
{ }^{\circ} \mathrm{C} \text { ) }\end{array}$ & $\begin{array}{c}\text { Temperature } \\
\text { With Soot }\left(\text { in }^{\circ} \mathrm{C}\right)\end{array}$ & Physical Observations \\
\hline $0: 00$ & & & \\
\hline $2: 00$ & & & \\
\hline $4: 00$ & & & \\
\hline $6: 00$ & & & \\
\hline $8: 00$ & & & \\
\hline 10:00 & & & \\
\hline $12: 00$ & & & \\
\hline $14: 00$ & & & \\
\hline $16: 00$ & & & \\
\hline 18:00 & & & \\
\hline $20: 00$ & & & \\
\hline $22: 00$ & & & \\
\hline 24:00 & & & \\
\hline $26: 00$ & & & \\
\hline 28:00 & & & \\
\hline 30:00 & & & \\
\hline
\end{tabular}




\section{Scattering and Absorption}

Directions: You will be developing and conducting an experiment comparing pure crushed ice or snow to crushed ice or snow with soot. List your materials and procedure BEFORE beginning your experiment. Make detailed observations and measurements while conducting your experiment. Following the experiment, you will be writing a lab report.

\section{Materials:}

\section{Procedure:}




\section{Data Table:}

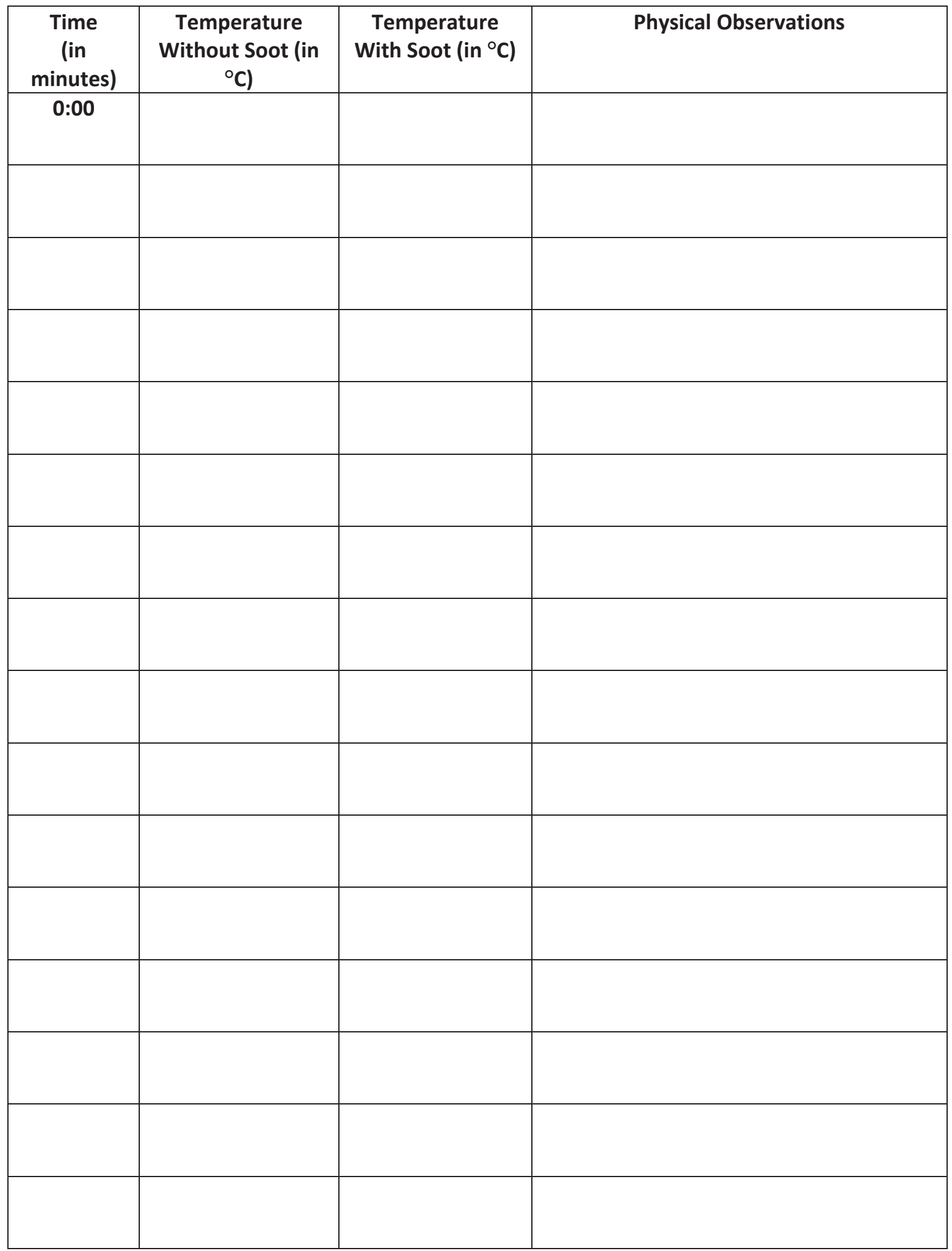




\section{Pico Project Video}

\section{Video Questions - part 1:}

1. Who first contacted Prof. Paulo Fialho and when?

2. What was Drs. Mazzoleni's relationship with Richard?

3. Where are other atmospheric stations located? Why are the stations on Pico and Mauna Loa unique?

4. When did the equipment arrive and how did it get to the top of the mountain?

5. In what year was the station installed?

6. Based on what you see in the video, why doesn't the team gather data in the winter?

7. Do scientists really use the "scientific method" as it is traditionally described?

8. What are the steps to get work published? How long does this take? 
9. Do all scientists understand everything? Do they ever have other scientists work on their projects? Why or why not?

10. How important is collaboration? Explain.

\section{Video Questions - part 2:}

11. How did the following team members get involved in the Pico Project and what is their role:

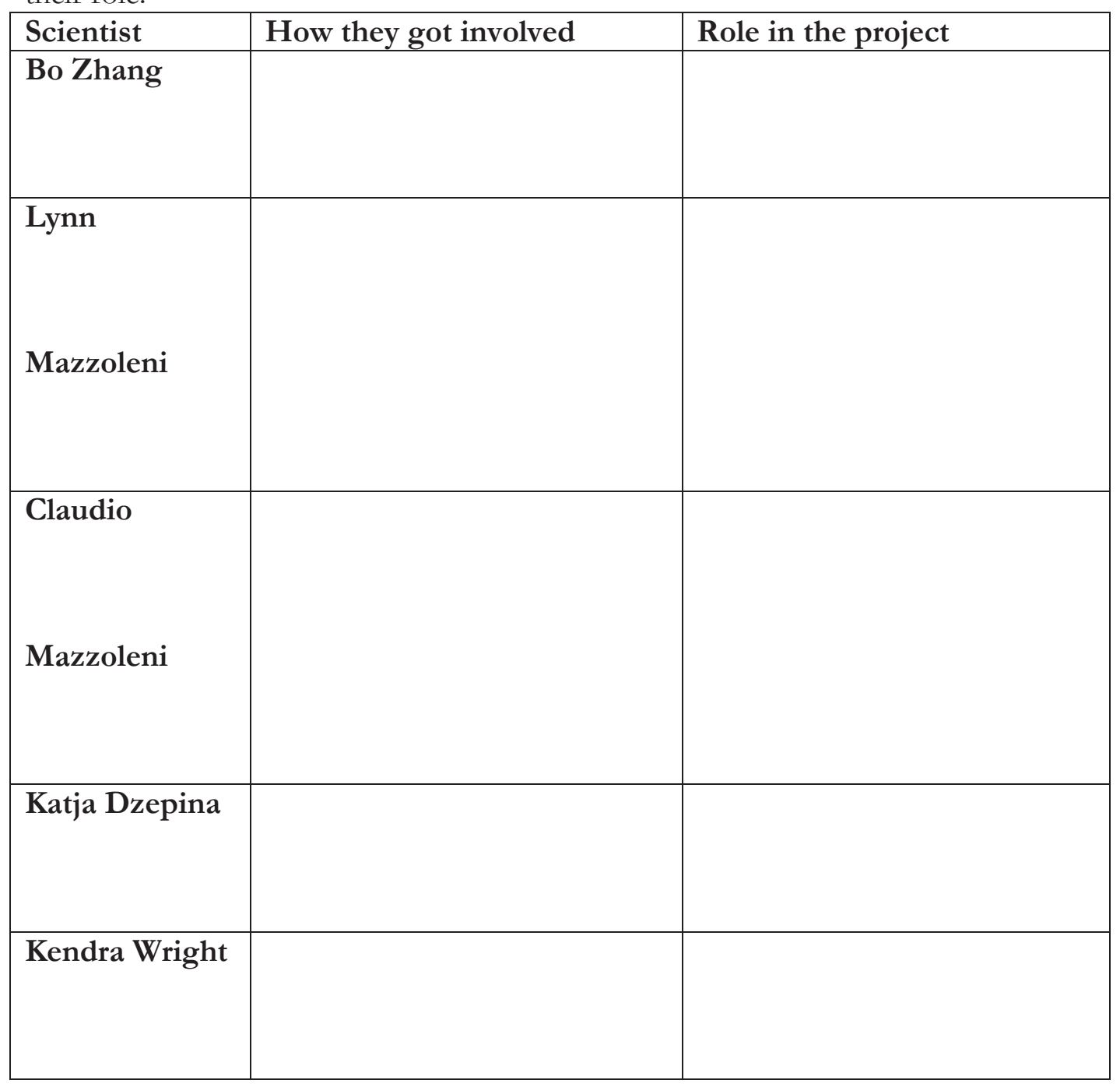


12. What are some of the roles other scientists have in the current project?

13. What do scientists gain from collaboration?

Think:

14. How did what you completed this unit relate to what actual scientists do?

15. Do you think it would be helpful to share ideas while doing experiments in class? Why or why not? 